
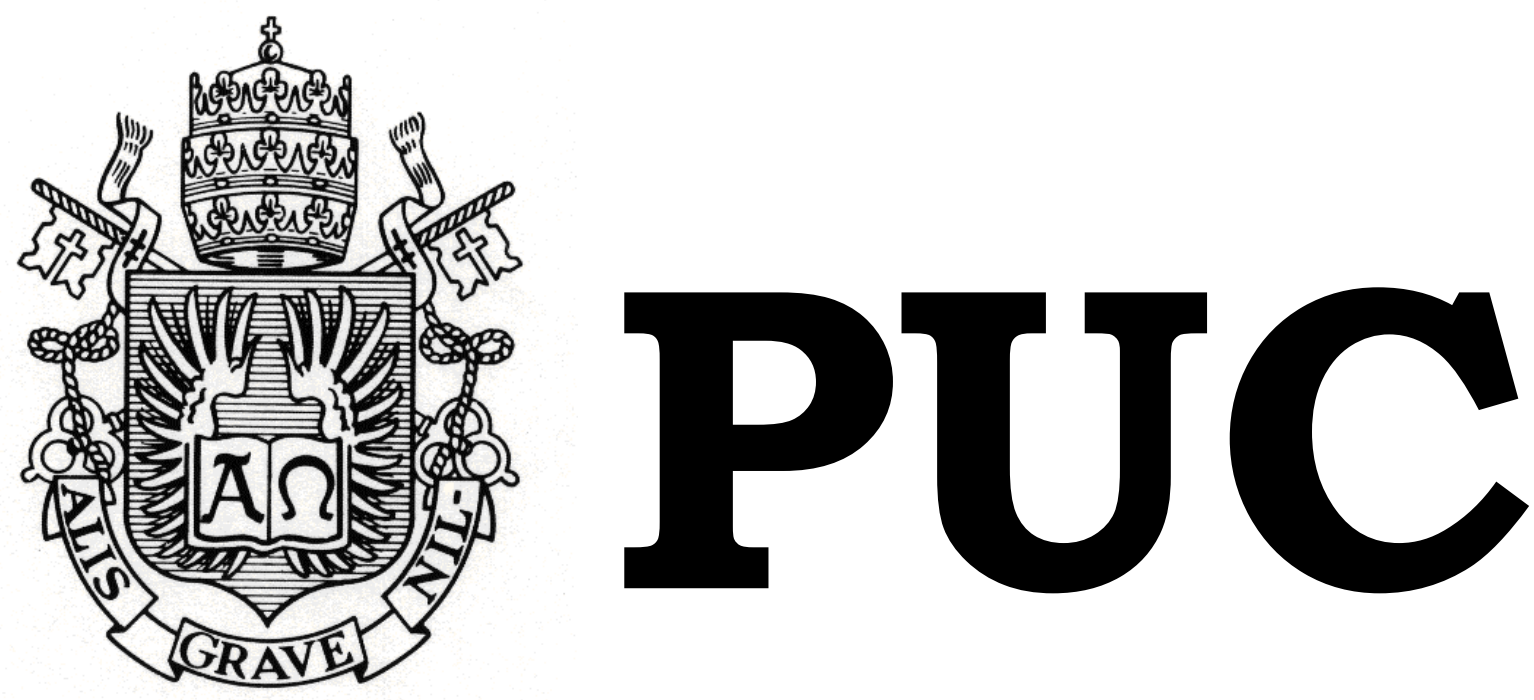

DEPARTAMENTO DE DIREITO

LIMITES E POSSIBILIDADES DO EXERCÍCIO DO DIREITO FUNDAMENTAL À LIBERDADE DE EXPRESSÃO: UMA PERSPECTIVA CONTEMPORÂNEA DA EXPERIÊNCIA CONSTITUCIONAL BRASILEIRA

por

MONIQUE SANTOS DE FREITAS

ORIENTADORA: REGINA COELI LISBOA SOARES

2018.2

PONTIFÍCIA UNIVERSIDADE CATÓLICA DO RIO DE JANEIRO RUA MARQUÊS DE SÃO VICENTE, 225 - CEP 22453-900 RIO DE JANEIRO - BRASIL 


\title{
LIMITES E POSSIBILIDADES DO EXERCÍCIO DO DIREITO FUNDAMENTAL À LIBERDADE DE EXPRESSÃO: UMA PERSPECTIVA CONTEMPORÂNEA DA EXPERIÊNCIA CONSTITUCIONAL BRASILEIRA
}

\author{
por \\ MONIQUE SANTOS DE FREITAS
}

Monografia apresentada ao Departamento de Direito da Pontificia Universidade Católica do Rio de Janeiro (PUCRio) para a obtenção do Título de Bacharel em Direito.

Orientadora: Regina

Coeli Lisboa Soares 


\section{DEDICATÓRIA}

"Desde o ventre materno dependo de ti; tu me sustentaste desde as entranhas da minha mãe. Eu sempre te louvarei! Tornei-me um exemplo para muitos, porque tu és o meu refúgio seguro. Do teu louvor transborda a minha boca, que o tempo todo proclama o teu esplendor." Salmos 71. 6-8

Dedico essa conquista, primeiramente, ao Dono da minha vida, Aquele que me permitiu chegar até o momento com louvor, sem o qual eu não teria conseguido percorrer sequer a metade dessa jornada, que está apenas começando.

Dedico também a todos que estiveram comigo durante esses 5 anos, compartilhando apoio, conhecimento $e$ alegrias.

Homenageio meus pais por serem o meu porto seguro nos momentos de maior dificuldade e fonte dos sorrisos mais sinceros diante de minhas conquistas. Pela luta para me proporcionar o que nunca tiveram. Vocês, sim, são meus orgulhos!

Minhas homenagens aos meus irmãos, que sempre foram meus grandes companheiros, aqueles que me ensinaram o valor de compartilhar e me ofereceram a proteção do verdadeiro amor. A fé que vocês depositam em mim me faz ir mais longe. Amo muito vocês.

Aos familiares, na pessoa dos meus avós, eu agradeço pelo amor dispensado, pelas conversas infindáveis, pelas lições e pelas orações que me fortaleceram $e$ continuarão me impulsionando a conquistar objetivos cada vez maiores.

Aos amigos que estiveram ao meu lado durante essa jornada, eu agradeço na pessoa da Beatriz Bacci. Sua sobriedade, apoio e amor simples foram essenciais à conclusão desta etapa. Da mesma forma sua família, vocês foram e sempre serão um grande exemplo para minha vida. Obrigada por TUDO! 


\section{AGRADECIMENTOS}

Gostaria de enaltecer a Regina que já admirava como pessoa e professora, mas que superou todas as minhas expectativas como orientadora. Foi calmaria e persistência, auxiliando-me sempre com solicitude e carinho. Muito obrigada!

Meus agradecimentos à Thula, que durante a graduação abriu meus olhos a temas tão sensíveis, fazendo-me enxergar a vida com mais empatia. Seu exemplo me inspira!

Por fim, meus sinceros agradecimentos ao Dr. Francesco Conte, figura ímpar, que a Procuradoria Geral do Estado me concedeu a honra e o prazer de conhecer. De quem obtive grandes lições de vida e apoio nos momentos de aflição e ansiedade durante a realização deste trabalho. Muito obrigada por sua amizade! 


\section{RESUMO}

FREITAS, Monique Santos de. Limites e Possibilidades do Exercício do Direito Fundamental à Liberdade de Expressão: Uma Perspectiva Contemporânea da Experiência Constitucional Brasileira. Rio de Janeiro: 2018: 64 p. Trabalho de Conclusão de Curso. Departamento de Direito da Pontifícia Universidade Católica do Rio de Janeiro - PUC-Rio.

O presente trabalho tem como objetivo o aclaramento sobre alguns pontos envolvendo o exercício da liberdade de expressão enquanto um direito constitucionalmente protegido. Chamando-se especial atenção ao Estado Democrático de Direito, como pano de fundo essencial para a defesa e manutenção das liberdades, assim como de seu regular exercício. Nesse contexto, faz-se necessário entender como as instituições democráticas têm acompanhado os avanços da sociedade, sobretudo, diante de conflitos de interesses sensíveis à dinâmica social.

Palavras-chave: Liberdade de Expressão; Constitucionalismo; Democracia; Discurso de Ódio; Liberdade de Imprensa; Ponderação. 


\section{SUMÁRIO}

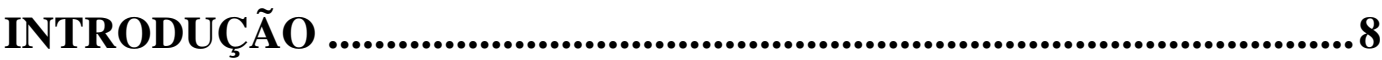

CAPÍTULO 1 - SUBSTRATO CONSTITUCIONAL DOS DIREITOS

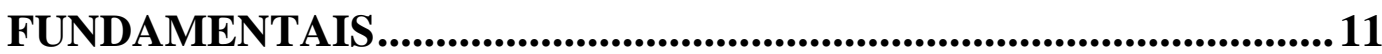

1.1 Constituição, Constitucionalismo e Democracia ............................... 11

1.1.1 Do Constitucionalismo Liberal ao Constitucionalismo Social.. 11

1.1.2 Centralidade e Supremacia da Constituição .............................. 14

1.2 Consolidação do Estado Constitucional Democrático de Direito..... 16

1.2.1 Reconhecimento de Força Normativa à Constituição ................. 18

1.3 O Papel do Estado na Efetiva Realização dos Direitos Fundamentais:

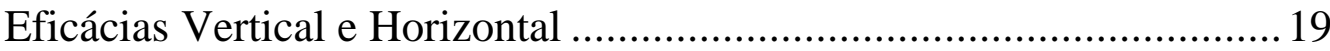

CAPÍTULO 2 - A LIBERDADE DE EXPRESSÃO COMO

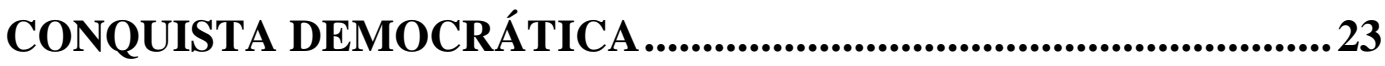

2.1 O Brasil em Períodos Autoritários ……………………………......23

2.2. A Liberdade de Expressão em Diplomas Internacionais...................25

2.3 Liberdade de Expressão na Constituição Federal de 1988 .................28

2.4 Possibilidade de Mitigação/Restrição do Exercício da Liberdade de

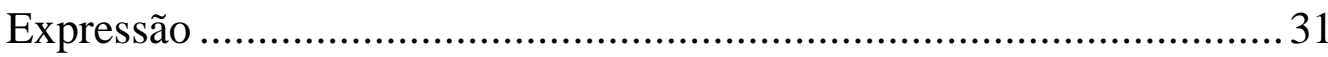

CAPÍTULO 3 - LIBERDADE X IGUALDADE: O PAPEL REGULATÓRIO DO ESTADO ......................................................36

3.1. Colisão Entre Normas Constitucionais: Técnica da Ponderação Como

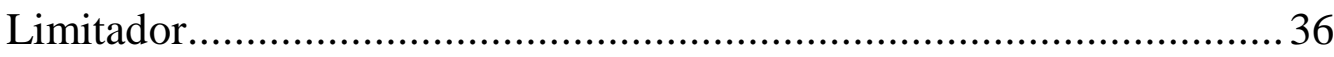

3.2. As Peculiaridades do Caso Concreto Como Critério de Prevalência do Direito Fundamental: Jurisprudência Brasileira ...................................... 40

3.3. Análise da Liberdade de Expressão e Discurso de Ódio nos EUA.. 42 3.3.1. Hate speech e a Primeira Emenda norte-americana: posição da

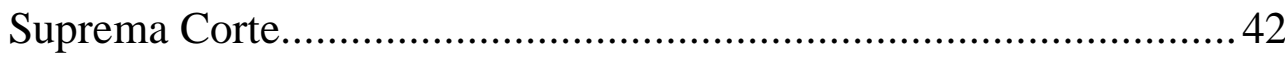

3.3.2. Regulação do Discurso de Ódio a Partir da Experiência Norte-

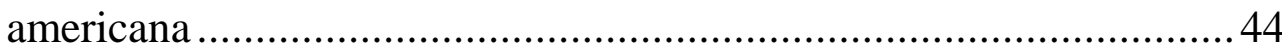


CAPÍTULO 4 - DESAFIOS ATUAIS 49

4.1. Liberdade de Imprensa: A Influência da Mídia como Óbice à Efetivação de Garantias Fundamentais 49

4.1.1. Os Excessos na Publicidade de Julgamentos Criminais 49

4.2. O protagonismo do Poder Judiciário no Campo da Realização dos Direitos Fundamentais: Influxo da Mídia e Seus Efeitos.........................52

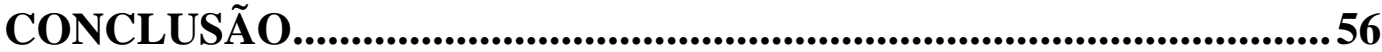
REFERÊNCIAS BIBLIOGRÁFICAS...............................................59 


\section{LISTA DE ABREVIAÇÕES}

ADI - Ação Direta de Inconstitucionalidade

ADPF - Arguição de Descumprimento de Preceito Fundamental

CRFB/1988 - Constituição da República Federativa do Brasil de 1988

STF - Supremo Tribunal Federal

$\mathrm{HC}$ - Habeas Corpus

RE - Recurso Extraordinário 


\section{INTRODUÇÃO}

A ascensão do Estado Constitucional Democrático de Direito deu causa a grandes avanços em termos de alcance das normas constitucionais e mecanismos voltados à sua efetivação. A interpretação constitucional também sofreu algumas alterações e tem tomado contornos específicos para acompanhar as mudanças ocorridas na sociedade. Resultado desse processo, a constitucionalização do direito apontou para a importância de garantir a observância dos direitos fundamentais, que passaram a irradiar para os demais ramos do Direito.

A dignidade da pessoa humana, tal como um princípio-regra, atingiu alto grau de importância e visibilidade no ordenamento jurídico, doutrina e jurisprudência. De modo que passou a ditar o sentido da interpretação constitucional.

No Brasil, a Constituição de 1988 coroou a redemocratização, ficando conhecida como Constituição Cidadã dada a ampla garantia de liberdades civis, acompanhadas da conquista de muitos direitos sociais.

A liberdade de expressão em suas múltiplas versões perfaz-se num princípio marcante e extremamente relevante na concretização e manutenção da democracia. A possibilidade de manifestação individual ou coletiva do pensamento, a liberdade de imprensa, a possibilidade de denunciar abusos de qualquer natureza, seja política ou institucional, representam conquistas grandiosas, mas sensíveis à dinâmica social.

Não se questiona a preocupação das instituições em garantir a efetivação dos direitos previstos na $\mathrm{CRFB} / 88$, mas, diante de um cenário em que a defesa das liberdades enfrenta obstáculos, não pode o Poder Judiciário furtar-se da incumbência de fazer cumprir com precisão os ditames constitucionais e os princípios inerentes à ordem constitucional. 
Em uma era na qual os avanços da mídia tradicional, seguida de novas mídias, ampliam em larga escala os canais de comunicação, há quase que uma superação do monopólio dos meios de comunicação em massa. Se por um lado, soa atraente a alternativa de outras vozes, outros pontos de vista sobre fatos do cotidiano, alguns problemas surgem em decorrência desse fenômeno, entre eles a profusão de notícias falsas ("fake news"), o que não será objeto do presente trabalho por não manter identidade com a liberdade de expressão, sequer como uma distorção do direito.

Para além dessa dificuldade, faz-se mister ressaltar o tema referente aos conflitos entre direitos fundamentais que, nessa toada, geram intensos debates em face do surgimento de casos difíceis ("hard cases"). Quando se chocam direitos como a liberdade de expressão e o direito à honra ou o direito à intimidade, ou, ainda, colisão entre liberdade de expressão e discurso de ódio, cabe ao juiz a solução do embate através da ponderação.

Não há consenso, não há conformidade, tampouco unanimidade diante do modo de solução de tais casos. Resta clara, portanto, a função dos doutrinadores, magistrados e, sobretudo, do próprio STF de buscar meios de compreensão do exercício das liberdades e suas consequentes implicações, seja na esfera pública ou na esfera privada, de modo a inviabilizar abusos de qualquer natureza.

Faz-se patente a necessidade de se discutir o tema, posto que as instituições públicas, que na lógica democrático-republicana, detém o poderdever de agir para garantir o cumprimento do ordenamento jurídico vigente, têm-se deparado com conflitos de direito cada vez mais sensíveis.

Assim como a colisão de direitos fundamentais pode se revelar um elemento dificultador na aplicação do direito pelo julgador, a espetacularização dos casos sob seu encargo, sobretudo na esfera criminal, pode se apresentar como uma barreira intransponível na busca de julgamentos justos. O protagonismo de verdadeiros "reality shows" por réus em ações penais, com excessiva exposição da mídia, acompanhados de 
informações carentes de fundamento, tem gerado um efeito direto sobre a atuação de juízes.

Para o alcance das reflexões que se almeja, no primeiro capítulo, abordaremos a trajetória do constitucionalismo no Brasil, a conquista da força normativa da Constituição Federal e o modo como o Estado realiza os direitos fundamentais.

No segundo capítulo, traçaremos um panorama histórico sobre o autoritarismo no poder e como a liberdade de expressão surge como uma ferramenta importante no processo de redemocratização do país.

No terceiro capítulo, veremos conflitos sensíveis de direitos fundamentais e o modo como a ponderação é capaz de oferecer auxílio para a solução dos casos difíceis. Nesse capítulo, discorreremos sobre o discurso de ódio e a diferença do tratamento no Brasil e nos EUA.

Já no último capítulo, faremos referência à influência da mídia nos julgamentos criminais, o modo como a mídia é capaz de influenciar o consenso/dissenso na sociedade e como o Poder Judiciário deve agir diante das pressões diante de casos que geram comoção social.

Para a concretização deste trabalho foi utilizada metodologia consistente, sobretudo, em pesquisa bibliográfica e jurisprudencial de diferentes autores e tribunais tanto do Brasil, como estrangeiros. Ainda nesse sentido, a pesquisa contou com a abordagem de artigos eletrônicos e matérias jornalísticas 


\section{CAPÍTULO 1 - SUBSTRATO CONSTITUCIONAL DOS DIREITOS FUNDAMENTAIS}

\subsection{Constituição, Constitucionalismo e Democracia}

\subsubsection{Do Constitucionalismo Liberal ao Constitucionalismo Social}

No seio do constitucionalismo moderno surge a ideia de limitação do poder do Estado com vistas à garantia de liberdades individuais. Despedindose do Estado absolutista da Idade Média e já vislumbrando um Estado liberal a tomar forma, ficava cada vez mais evidente que o modelo então vigente não dava conta da complexidade daquela sociedade. Nesse sentido, as grandes Revoluções tiveram papel essencial para essa virada e contribuíram ainda que de maneira introdutória para a estruturação do constitucionalismo.

A superação do absolutismo, no qual os monarcas não se sujeitavam a leis ou ao Direito, representou o marco desse movimento. O constitucionalismo que surgia apresentava três características principais, quais sejam: a limitação do poder dos governantes, através da separação de poderes; a garantia dos direitos e liberdades individuais oponíveis ao Estado; e a democracia representativa, partindo da necessidade de legitimação do governo através do consentimento dos governados ${ }^{1}$.

A Europa do século XVIII experimentava um momento de insegurança, a Revolução Francesa fez com que o parlamento assumisse a posição de protagonista na consolidação do regime democrático, pois, por meio dele, e apenas dele, os franceses acreditavam que seria possível a manutenção da ordem democrática. Dessa forma, o constitucionalismo francês surge diante de um cenário de incertezas e esperança na figura do parlamento. Por essa razão, o sistema francês baseava-se na chamada supremacia do Legislativo.

\footnotetext{
${ }^{1}$ NETO, Cláudio Pereira de Souza; SARMENTO, Daniel. Direito Constitucional: teoria, história e métodos de trabalho. Belo Horizonte: Fórum, 2014. p. 72.
} 
O constitucionalismo liberal-burguês, baseado na ideia de Estado mínimo, defendia a garantia dos direitos fundamentais através de uma atuação negativa do Estado. Ou seja, defendia-se a não intervenção na economia e a abstenção do Estado quanto a intervenções de natureza social. Nesse contexto, a igualdade que se propunha possuía caráter meramente formal.

A liberdade real das pessoas, pressuposto para a existência de condições mínimas que possibilitem a cada um fazer conscientemente as suas escolhas, não configurava uma preocupação do Estado. Além disso, o enfoque projetava-se mais sobre as liberdades econômicas do que sobre as liberdades existenciais. Esse modelo passou a sofrer duras críticas, o que propiciou a emergência de um novo constitucionalismo, marcado pelo respeito à dignidade humana.

O Constitucionalismo Social constitui uma resposta aos abusos decorrentes do modelo liberal. As constituições sujeitas a esse modelo incorporam direitos sociais, que demandam prestações positivas do Estado, de modo a garantir a proteção dos direitos fundamentais, assim como a criação das condiçõos necessárias para seu exercício. A constituição de 1988 corresponde a uma típica Constituição social.

Atualmente, a Inglaterra possui uma constituição não escrita, ou seja, a Constituição é formada por leis criadas pelo Parlamento, que podem ser por ele alteradas a qualquer tempo. No Reino Unido não há que se falar em soberania da constituição, tal como concebida nos países que admitem o controle de constitucionalidade das leis, mas há, por sua vez, a supremacia do parlamento, que constitui o princípio constitucional de maior relevância. O parlamento indica e destitui o primeiro ministro, que possui o poder de dissolver o parlamento e convocar eleições. Isso advém da ideia de respeito às tradições e confere à constituição britânica grande flexibilidade. Hoje, tem-se mitigado a soberania irrestrita do Parlamento, ao menos quanto aos direitos fundamentais. 
O constitucionalismo americano por sua vez nasceu sob uma forte desconfiança da figura do parlamento, já que este silenciava quanto as atrocidades cometidas pelos regimes absolutistas. Assim, apesar do poder e dos meios que o parlamento inglês tinha para exercer controle sobre os atos do monarca não o fazia. De tal modo que, para os norte-americanos, o poder atribuído ao parlamento deveria ser fortemente limitado. Assim, o constitucionalismo americano surge sob a compreensão de que à constituição caberia a organização do Estado e limitação da ação dos governantes, não se lhe atribuindo a definição dos rumos do país.

Nos Estados Unidos, a previsão do controle de constitucionalidade não encontra previsão expressa no texto constitucional, mas decorreu fundamentalmente do julgamento do caso Marbury v. Madison ${ }^{2}$. O controle de constitucionalidade (judicial review) pode ser exercido por qualquer juiz diante de um caso concreto, através do controle difuso, ao mesmo tempo caracteriza-se por ser um controle concreto, pois ocorre diante de um conflito entre sujeitos de direito. Por se tratar de um país submetido ao sistema da common law, os precedentes judiciais são obrigatórios e vinculantes no tocante ao caso sucessivo. Deste modo, obrigam a todos os órgãos do Judiciário, assim como da Administração Pública³.

A Suprema corte norte-americana é o órgão responsável pelo controle de constitucionalidade, através de julgamentos de casos concretos que afastam ou aplicam determinada lei, tornando-se precedentes vinculantes. A função jurisdicional, principalmente nessa matéria, é de natureza essencialmente política.

No tocante à realidade brasileira, avulta a dificuldade contramajoritária ${ }^{4}$, que tem suscitado incandescentes debates doutrinários, já

\footnotetext{
${ }^{2}$ MARSHALL, John, and Supreme Court Of The United States. U.S. Reports: Marbury v. Madison, 5 U.S. 1 Cranch 137. 1803. Periodical. Retrieved from the Library of Congress. Disponível em http://cdn.loc.gov/service/11/usrep/usrep005/usrep005137/usrep005137.pdf. Acesso em 29 set. 2018 ${ }^{3}$ NETO; SARMENTO, 2016, p. 31.

4 "A legitimidade democrática da jurisdição constitucional tem sido questionada em razão da apontada "dificuldade contramajoritária" do Poder Judiciário, que decorre do fato de os juízes, apesar de não serem eleitos, poderem invalidar as decisões adotadas pelo legislador escolhido pelo
} 
que a legitimidade democrática conferida pelo povo está com os legisladores e não com o Judiciário. Tal decorre da circunstância de que, no Brasil, os juízes não são ungidos pelo sufrágio popular'; antes, ao contrário, são selecionados através de concursos públicos de provas e títulos, de acordo com o art. 93, I da Constituição Federal ${ }^{6}$.

\subsubsection{Centralidade e Supremacia da Constituição}

A Constituição, tal como concebida atualmente, vem passando por diversas transformações desde seu surgimento como documento responsável pela organização do Estado e limitação do poder político. A ideia de supremacia do texto constitucional, representada pela pirâmide ${ }^{7}$, demonstra que o ordenamento jurídico rege-se pelas normas contidas na Constituição, normas que surgem do poder constituinte originário e derivado e detém estabilidade.

Tal como a supremacia, a centralidade da Constituição foi reconhecida e vem sendo reafirmada. A centralidade vem indicando para a supremacia material da Constituição. De modo que, a constitucionalização do direito brasileiro, movimento que reconhece a sujeição de todo o ordenamento jurídico aos ditames do texto constitucional, representou importante avanço

\footnotetext{
povo, invocando, muitas vezes, normas constitucionais de caráter aberto, que são objeto de leituras divergentes na sociedade." (NETO; SARMENTO, 2016, p. 35).

${ }^{5}$ CONTE, Francesco. Sobre a motivação da sentença no processo civil: Estado constitucional democrático de direito, discurso justificativo e legitimação do exercício da jurisdição. $1^{\mathrm{a}} \mathrm{ed}$. Rio de Janeiro: Gramma, 2016. p. 887

${ }^{6}$ Art. 93. Lei complementar, de iniciativa do Supremo Tribunal Federal, disporá sobre o Estatuto da Magistratura, observados os seguintes princípios:

I - ingresso na carreira, cujo cargo inicial será o de juiz substituto, mediante concurso público de provas e títulos, com a participação da Ordem dos Advogados do Brasil em todas as fases, exigindose do bacharel em direito, no mínimo, três anos de atividade jurídica e obedecendo-se, nas nomeações, à ordem de classificação;

${ }^{7}$ A Teoria Pura do Direito, proposta por Hans Kelsen, consubstanciada na figura da pirâmide está bem mais relacionada à supremacia da constituição em termos formais. Ou seja, a alocação da constituição no topo da pirâmide demonstrava que a lei Suprema vinculava muito mais no plano formal do que material.
} 
no que toca a prevalência dos direitos fundamentais diante dos constantes processos de mudança no seio da sociedade ${ }^{8}$.

No primeiro momento do constitucionalismo liberal, a supremacia da constituição manifestava-se, quanto à limitação do poder político, na criação dos poderes constituídos que a ela se submetiam e eram responsáveis pela criação das leis, atos administrativos e decisões judiciais. Essa supremacia constitucional fundamentava-se, basicamente, no conteúdo das normas que lhe pertenciam. Por esse motivo, denominada supremacia material.

Todavia, foi no decorrer dos séculos XIX e XX, que paulatinamente esse cenário foi se alterando. As maiorias que passaram a se formar no curso dos processos constituintes inseriam temas de seu interesse no texto constitucional com o objetivo de protegê-los, sob a estabilidade conferida à constituição. Assim, a supremacia material passava a dar lugar à supremacia formal.

Um dos fundamentos que afirma a supremacia da constituição possui natureza substantiva e está diretamente ligado ao conteúdo do texto normativo, já o outro diz respeito à origem da norma. Quanto ao fundamento objetivo, entende-se que tais normas constituem núcleo essencial de proteção ${ }^{9}$.

A supremacia da constituição materializa-se através da rigidez constitucional e do controle de constitucionalidade dos atos normativos. Por rigidez, entende-se que o processo de alteração de preceitos constitucionais deve obedecer a um procedimento mais complexo que o estabelecido para a criação de leis ordinárias. O controle de constitucionalidade, por sua vez,

\footnotetext{
8 "O Estado Constitucional de Direito tem como fito garantir, como razão mesma de sua existência, direitos fundamentais, individuais ou coletivos (v. g., liberdade, igualdade, segurança, justiça), perante o poder estatal. No escopo de prevenirem-se rasgos autoritários e abusos de poder político, em diferentes estruturas sócio-econômico-cultural-políticas.” ( CONTE, 2016, p. 272).

9 "Em síntese, a ideia é a de que existem direitos e princípios tão essenciais que devem ser postos fora do alcance das maiorias. Por isso, eles são "entrincheirados" pela Constituição, que os protege até do legislador democraticamente eleito. (...) Basta reconhecer que existem certos valores - não importa se históricos ou transcendentes — que são tão importantes que devem ser subtraídos da luta política cotidiana." (NETO; SARMENTO, 2016, p. 89)
} 
admite a invalidação de atos normativos que contrariem a normativas constitucionais. ${ }^{10}$

\subsection{Consolidação do Estado Constitucional Democrático de Direito}

O conceito de Estado de Direito, em sua origem, era ligado ao liberalismo e caracterizava-se pela sujeição às leis. Essa lei formalmente emanada do Poder Legislativo garantia os direitos individuais de seus representados.

O chamado império da lei pressupunha uma atuação governamental vinculada a normas legais emanadas de órgãos competentes e que, portanto, detém legitimidade. Essas normas são dotadas de abstratividade, generalidade e irretroatividade, o que lhes confere o poder de sujeitar os atos de quem detém o poder de definir os rumos da vida do povo ${ }^{11}$.

Contudo, esse conceito de Estado de Direito, e suas implicações, passou a não dar conta da complexidade das relações que se estabeleciam, dada a amplitude de seu significado, o que fez com que a expressão 'Estado de Direito' passasse a ser vista como uma expressão ambígua e insuficiente. Isto porque, apesar de garantir a criação e aplicação das leis não criava mecanismos para controlar seu conteúdo, desembocando na legitimação de regimes autoritários, tal como o Estado fascista ${ }^{12}$.

\footnotetext{
${ }^{10}$ Daniel Sarmento soma a estes um elemento sociológico, o qual ele denomina de "cultura constitucional", a qual caracteriza-se por uma adesão generalizada do povo à Constituição estatal que, segundo ele "ocorre quando este a toma como algo que é seu, e pelo qual vale a pena lutar." 11 "O Estado de Direito caracteriza-se por apresentar as seguintes premissas: (1) primazia da lei, (2 ) sistema hierárquico de normas que preserva a segurança jurídica e que se concretiza na diferente natureza das distintas normas e em seu correspondente âmbito de validade; (3) observância obrigat ória da legalidade pela administração pública; (4) separação de poderes como garantia da liberdade ou controle de possíveis abusos; (5) reconhecimento da personalidade jurídica do Estado, que mant ém relações jurídicas com os cidadãos; (6) reconhecimento e garantia dos direitos fundamentais inc orporados à ordem constitucional; (7) em alguns casos, a existência de controle de constitucionalid ade das leis como garantia ante o despotismo do Legislativo." (MORAES, Alexandre de. Direito c onstitucional. - 29. ed. - São Paulo: Atlas, 2013. p. 5)

${ }^{12}$ SILVA, José Afonso da. Curso de direito constitucional positivo. $41^{\mathrm{a}}$ ed., rev. e atual./até a Emenda Constitucional n. 99, de 14.12.2017. São Paulo: Malheiros, 2018, p.115.
} 
O Estado Social de Direito surge como resposta ao Estado Liberal, abandonando a neutralidade e o individualismo típicos do liberalismo para pensar uma nova forma de atender aos anseios sociais que surgiram das grandes injustiças cometidas sob o amparo da lei. Apesar da tentativa de criar um estado de bem-estar, essa concepção de Estado ainda se apresentava insuficiente e imprecisa.

Em decorrência de tais desdobramentos nasce o Estado Democrático de Direito, cujo princípio norteador é a soberania popular; este pressupõe a atuação do povo com vistas a realização, em última ratio, da justiça social. A democracia realizada pelo Estado Democrático de Direito, segundo dispõe o artigo 3o, I da Constituição Federal, pressupõe um processo de convivência numa sociedade livre, justa e solidária.

O Estado Constitucional de Direito insere o elemento constitucional ao conceito de Estado para demonstrar a estabilidade dos direitos fundamentais que se pretende promover, como resposta às atrocidades cometidas pelo regime nazista sob o amparo das leis. Esse modelo que surge passa a sujeitar a atuação do legislador ao que dispõe à constituição, documento mais importante do ordenamento jurídico e que condiciona a existência e validade de todas as normas infraconstitucionais ${ }^{13}$.

Nesse cenário, ganham força princípios como: princípio da constitucionalidade; o princípio democrático (art. $1^{\circ}$ ); o princípio da justiça social (art. 170 e 193), o princípio da igualdade (art. $5^{\circ}$, caput e I); princípio da separação de poderes (art. $2^{\circ}$ ); o princípio da legalidade (art. $5^{\circ}$, I) e princípio da segurança jurídica (art. $5^{\circ}$, XXXVI a LXXIII). ${ }^{14}$

\footnotetext{
13 “O Estado constitucional, portanto, é mais do que o Estado de Direito, é também o Estado Demo crático, introduzido no constitucionalismo como garantia de legitimação e limitação do poder" (M ORAES, Alexandre. p. 6).

${ }^{14}$ SILVA, 2018, p. 124.
} 


\subsubsection{Reconhecimento de Força Normativa à Constituição}

A afirmação de que a constituição corresponde a norma jurídica não foi certeza pacífica sempre. Após o fim da II Grande Guerra, instaurou-se um cenário de descrença nas autoridades políticas. Nesse contexto, as constituições que surgiam estabeleciam direitos fundamentais, os quais deveriam ser autoaplicáveis para impedir atrocidades de modelos autoritários.

No mesmo momento, e em decorrência desse movimento, houve o fortalecimento da jurisdição constitucional com vistas a dar efetividade às normas contidas na constituição. No Brasil, esse processo de reconhecimento iniciou-se em momento posterior à redemocratização, com a promulgação da Constituição de 1988. Essa discussão, portanto, chegou ao Brasil apenas na década de 80, tendo a Constituição de 1988 assumido importante papel nesse processo de reconhecimento e aplicação de suas normas. A partir de então as normas constitucionais ganharam relevo muito maior, apesar de ainda não lhes ser atribuída total efetividade.

Nesse sentido, a atuação do poder constituinte, em qualquer de suas formas, possui o encargo de positivar no texto constitucional a tradução da vontade do povo, por meio de normas que representem, sobretudo, as mudanças sociais experimentadas ao longo dos anos. Isso nos permite inferir que, apesar de sua rigidez, a Constituição não representa um documento estático, mas apto a sofrer alterações e produzir efeitos em diferentes cenários da história ${ }^{15}$.

\footnotetext{
${ }^{15}$ Konrad Hesse afirma: "A constituição não configura, portanto, apenas expressão de um ser, mas também de um dever ser; ela significa mais do que o simples reflexo das condições fáticas de sua vigência, particularmente as forças sociais e políticas. Graças à pretensão de eficácia, a constituição procura imprimir ordem e conformação à realidade política e social. Determinada pela realidade social e, ao mesmo tempo, determinante em relação a ela, não se pode definir como fundamental nem a pura normatividade, nem a simples eficácia das condições sócio-políticas e econômicas. A força condicionante da realidade e a normatividade da constituição podem ser diferenciadas; elas não podem, todavia, ser definitivamente separadas ou confundidas." (HESSE, Konrad. A força normativa da constituição. - Tradução de Gilmar Ferreira Mendes. Sergio Antonio Fabris Editor. Porto Alegre, 1991).
} 
Partindo desse entendimento, é possível afirmar que os direitos previstos na Constituição devem ser observados e garantidos pelo Estado por meio de uma atuação positiva, não cabendo abstenção em questões que demandam ações efetivas. Isso significa que o Estado deve promover a efetivação dos direitos constitucionais, sobretudo, os direitos fundamentais.

\subsection{O Papel do Estado na Efetiva Realização dos Direitos Fundamentais: Eficácias Vertical e Horizontal}

O processo de formação do Estado brasileiro foi marcado por momentos de grande instabilidade política. Desde a chegada dos colonizadores até os dias atuais raros foram os momentos em que se experimentou a efetivação das leis, em estreita conformidade com a Constituição.

Assim como em diversas partes do mundo, a Constituição no Brasil sempre representou muito mais um documento político, sujeito às mudanças no campo político do que um documento jurídico capaz de estabelecer normas autoaplicáveis. Um exemplo é suficiente para ilustrar a afirmação: a Carta de 1967/69, que garantia os direitos à liberdade, à integridade física e à vida, não sendo raras, contudo, as prisões ilegais, o desaparecimento forçado de pessoas e a tortura do regime militar.

No curso do século XX, conforme demonstrado em tópico anterior, a constituição ganha força normativa. Suas disposições passam a ter o caráter vinculativo e obrigatório reconhecidos, o que foi essencial para se garantir a transição de um modelo autoritário para um regime efetivamente democrático, nos moldes que se propunha.

Atualmente, não se pode questionar o importante papel exercido pelo Estado na promoção e garantia dos direitos fundamentais. Isso porquê, conforme já visto, em modelos anteriores, interesses limitados de poucos 
detentores do poder econômico foram capazes de reduzir a nada determinados direitos ligados à própria dignidade humana ${ }^{16}$.

A eficácia vertical dos direitos fundamentais está fundada na possibilidade de realização de determinados direitos mediante imposição do poder do Estado. Isso significa que a sociedade está sujeita à atuação do Estado visando a efetiva realização de direitos fundamentais aos seus cidadãos. Desta forma, as liberdades demandam, em regra, atuação negativa ou uma abstenção estatal. Nesse sentido, vale dizer que a liberdade jurídica, concebida como direito, pressupõe que a pessoa não sofra qualquer óbice por parte do Estado em suas ações, impedindo-se, dessa forma, qualquer ingerência estatal em relação à garantia do direito à liberdade.

Contudo, violações de direitos fundamentais podem ter sua origem para além da pessoa do Estado, mas perpetradas por terceiros, em decorrência de relações entre particulares. Não por acaso, na matéria, despontou, na Alemanha como resultado de intensos debates doutrinários e jurisprudenciais, a teoria da eficácia horizontal dos direitos fundamentais.

Não é de todo inquestionável a possibilidade de oposição de direitos fundamentais a particulares e muita resistência surgiu acerca dessa possibilidade $^{17}$. Apesar da ausência de contornos claros no que se refere a

\footnotetext{
${ }^{16}$ Afina-se pelo mesmo diapasão o magistério de Luís Roberto Barroso: "O Estado ainda é a grande instituição do mundo moderno. Mesmo quando se fala em centralidade dos direitos fundamentais, o que está em questão são os deveres de abstenção ou de atuação promocional do poder público. Superados os preconceitos liberais, a doutrina publicista reconhece o papel indispensável do Estado na entrega de prestações positivas e na proteção diante da atuação abusiva dos particulares" (BARROSO, Luís Roberto. Interpretação e aplicação da constituição: fundamentos de uma dogmática constitucional transformadora. 3ed., Saraiva. São Paulo, 1999. p. 126)

${ }^{17}$ No julgamento do RE 201.819/RJ, o Ministro Gilmar Mendes em seu voto-vista apresentou alguns argumentos que perpassam a ideia de eficácia horizontal dos direitos fundamentais numa análise da Lei Fundamental alemã, ele declarou: "Afirmou-se, ainda, que a eficácia imediata dos direitos fundamentais sobre as relações privadas acabaria por suprimir o princípio da autonomia privada, alterando profundamente o próprio significado do Direito Privado como um todo. Ademais, a aplicação direta dos direitos fundamentais às relações privadas encontraria óbice insuperável no fato de que, ao contrário da relação Estado-cidadão, os sujeitos dessas relações merecem e reclamam, em princípio, a mesma proteção. É claro que o tema prepara algumas dificuldades. Poder-se-ia argumentar com a disposição constante do art. 1, da Lei Fundamental, segundo a qual 'os direitos humanos configuram o fundamento de toda a sociedade' (Grundlage jeder Gemeinschaft). Poderse-ia aduzir, ainda, que a existência de forças sociais específicas, como os conglomerados econômicos, sindicatos e associações patronais, enfraquece sobremaneira o argumento da igualdade entre os entes privados, exigindo que se reconheça, em determinada medida, a aplicação dos direitos
} 
esse tema, tem-se admitido no direito brasileiro a aplicação dos direitos fundamentais em relações exclusivamente privadas, assim como no julgamento do Recurso Extraordinário 201.819/RJ, no qual um ex-membro da União dos compositores do Brasil, excluído do quadro de associados sem a observância da garantia ao contraditório e à ampla defesa e do devido processo legal teve tais direitos reconhecidos. A decisão declarou a limitação da autonomia privada, determinando que tais princípios constitucionais fossem respeitados no caso particular.

Nessa moldura, pode-se dizer que não há de se considerar uma ordem jurídica estática, alheia ao dinamismo da realidade social, tampouco um Estado neutro no que tange às relações privadas, no qual o pacta sunt servanda não estaria sujeito a qualquer tipo de controle.

Quanto à eficácia mediata dos direitos fundamentais, Alexy adota a Teoria da Irradiação $^{18}$, por meio da qual se entende que os direitos fundamentais irradiam sobre a totalidade do ordenamento jurídico vigente. Nesse sentido, as normas de direito fundamental não se adstringem à defesa de direitos subjetivos individuais, mas representam um sistema orgânico em que as decisões em âmbito constitucional são válidas tanto para o Legislativo, como para a Administração e a própria Jurisdição ${ }^{19}$.

\footnotetext{
fundamentais também às relações privadas. Esses dois argumentos carecem, todavia, de força normativa, uma vez que tanto o texto da Lei Fundamental, quanto a própria história do desenvolvimento desses direitos não autorizam a conclusão em favor de uma aplicação direta e imediata dos direitos fundamentais às relações privadas. (...) é preciso acentuar que diferentemente do que ocorre na relação direta entre o Estado e o cidadão, na qual a pretensão outorgada ao indivíduo limita a ação do Poder Público, a eficácia mediata dos direitos fundamentais refere-se primariamente a uma relação privada entre cidadãos, de modo que o reconhecimento do direito de alguém implica o sacrifício de faculdades reconhecidas a outrem. Em outros termos, a eficácia mediata dos direitos está frequentemente relacionada com um caso de colisão de direitos. A posição jurídica de um indivíduo em face de outro somente pode prevalecer na medida em que se reconhece a prevalência de determinados interesses sobre outros."

18 ALEXY, Robert. Teoría de los Derechos Fundamentales. - de la traduccion y estudio introductorio, Carlos Bernal Pulido. - Centro de Estudios Políticos y Constitucionales. - Madrid, 2014, p. 465.

${ }^{19}$ Confira-se, no ponto, Alexy: "El carácter objetivo no puede consistir en que los principios de derecho fundamental, en cuanto principios supremos del sistema jurídico, no tengan nada que ver com posiciones individuales. Esto contradiría la orientación básica de los derechos fundamentales, referida al individuo" (Ibid., p. 466).
} 
À luz de tais circunstâncias, é de se reafirmar o compromisso do ordenamento jurídico, sobretudo da Constituição Federal, assim como, em alguma medida, os esforços da jurisprudência no sentido de garantir a efetiva aplicação dos direitos fundamentais seja para proteger indivíduos ou a própria sociedade da atuação do Estado (eficácia vertical), bem ainda de particulares (eficácia horizontal). 


\section{CAPÍTULO 2 - A LIBERDADE DE EXPRESSÃO COMO CONQUISTA DEMOCRÁTICA}

\subsection{O Brasil em Períodos Autoritários}

A história se ocupa em demonstrar que, por vezes, a reprodução e o endosso de determinados discursos foi a alavanca capaz de produzir grandes tragédias, como os infaustos genocídios da humanidade. Essas práticas destrutivas, comumente, encontravam apoio na própria legislação, que não dispunha de procedimento legislativo que lhe garantisse legitimidade democrática e, ainda, carecia de mecanismos de controle com vistas ao equilíbrio da ordem social ${ }^{20}$.

Desde a chegada dos colonizadores em território brasileiro, quem aqui estava sofreu com uma série de imposições, seguidas de massacres. Povos indígenas foram obrigados a adotar o estilo de vida do homem branco, sob pena de extermínio, o que resultou em um verdadeiro genocídio ${ }^{21}$.

No século XIX, sob a vigência do império, a Constituinte de 1823, inspirada na França, teve um certo caráter revolucionário na tentativa de dar os primeiros passos em direção a uma representatividade democrática, consubstanciada numa constituição. Entretanto, ainda sob o domínio de Portugal, a Constituinte foi dissolvida pela suspeita de golpe. Neste cenário,

\footnotetext{
20 “Ao emergir da Segunda Guerra Mundial, após três lustros de massacres e atrocidades de toda sorte, iniciados com o fortalecimento do totalitarismo estatal iniciado nos anos 30, a humanidade compreendeu, mais do que em qualquer outra época da história, o valor supremo da dignidade humana." (COMPARATO, Fábio Konder. A afirmação histórica dos direitos. $10^{\mathrm{a}}$ ed. São Paulo: Saraiva, 2015, p. 68.)

${ }^{21}$ Darcy Ribeiro cunha a expressão "moinhos de gastar gente", referindo-se aos negros e índios massacrados pela expansão portuguesa em território brasileiro. Índios tidos como mercadoria abundante, tanto para uso próprio como para a venda e negros trazidos para servirem de escravos representavam a alavanca de "desenvolvimento econômico" comandada pelos portugueses. (RIBEIRO, Darcy. Povo brasileiro: a formação e o sentido do Brasil. São Paulo: Companhia das Letras, 1995. p. 106.)
} 
alguns membros da assembleia foram presos, exilados e, posteriormente, deportados 22 .

Igualmente despóticos foram os períodos dominados pelas ditaduras no Brasil. Nos anos pós 1964, em que prevaleceu a ditadura militar no País, a censura constituiu ferramenta importante para a manutenção do regime. Através das diversas formas de repressão ao livre pensar e expressar crenças e opiniões, os militares impunham seu modelo de governo. Sem nenhum compromisso com as liberdades individuais ou com os direitos fundamentais, os operadores do regime procediam prisões sem observância a qualquer tipo de procedimento que garantisse o devido processo legal.

Os Atos Institucionais, por sua vez, funcionavam como base legal para práticas totalmente dissonantes de garantias mínimas relacionadas à dignidade humana.

A Lei de Imprensa ${ }^{23}$, publicada em 9 de fevereiro de 1967, impedia que a imprensa e órgãos de comunicação fizessem a transmissão de fatos que aconteciam ao redor do país naquele período. A censura era evidente e silenciava os canais de comunicação para favorecer o regime autoritário. Além de não haver liberdade para jornalistas, essa lei previa uma série de sanções severas a quem descumprisse suas disposições. O seu art. $2^{\text {o24 }}$ lançou

\footnotetext{
${ }^{22}$ RODRIGUES, José Honório. A assembleia constituinte de 1823. Editora Vozes. Petrópolis, 1974. p. 223.

${ }^{23}$ A Lei $n^{\circ} 5.250$ de 09 de fevereiro de 1967 trazia previsões que, claramente, atentavam contra as liberdades individuais e coletivas tais como:

Art. $1^{\circ}$ É livre a manifestação do pensamento e a procura, o recebimento e a difusão de informações ou idéias, por qualquer meio, e sem dependência de censura, respondendo cada um, nos têrmos da lei, pelos abusos que cometer.

$\S 1^{\circ}$ Não será tolerada a propaganda de guerra, de processos de subversão da ordem política e social ou de preconceitos de raça ou classe.

$\S 2^{\circ} \mathrm{O}$ disposto neste artigo não se aplica a espetáculos e diversões públicas, que ficarão sujeitos à censura, na forma da lei, nem na vigência do estado de sítio, quando o Govêrno poderá exercer a censura sôbre os jornais ou periódicos e emprêsas de radiodifusão e agências noticiosas nas matérias atinentes aos motivos que o determinaram, como também em relação aos executores daquela medida. (BRASIL. Lei ${ }^{\circ}$ 5.250, de 09 de fevereiro de 1967. Regula a liberdade de manifestação do pensamento e de informação. Disponível em:

http://www.planalto.gov.br/ccivil_03/LEIS/L5250.htm. Acesso em 13 jul. 2018.)

${ }^{24}$ Art. $2^{\circ}$ É livre a publicação e circulação, no território nacional, de livros e de jornais e outros periódicos, salvo se clandestinos (art. 11) ou quando atentem contra a moral e os bons costumes. (BRASIL. Lei ${ }^{\circ}$ 5.250, de 09 de fevereiro de 1967. Regula a liberdade de manifestação do pensamento e de informação. Disponível em:
} 
mão do conceito demasiado aberto de "bons costumes" para dizer que sua violação resultaria na impossibilidade de circulação do jornal.

Além dos jornalistas, tantos outros foram silenciados pelo regime, entre eles artistas e intelectuais que se uniam para combater os ideais impostos pela ditadura.

Por essa razão, a redemocratização inspira a inexistência de espaço para um modelo de Estado em que uma vontade tida como soberana deva prevalecer, até porque a democracia, fruto desse processo histórico, pressupõe governo feito pelo povo e destinado ao povo, legítimo detentor do poder estatal, nos termos do art. $1^{\circ}$, parágrafo único da Constituição Federal $^{25}$. Dessa maneira, logo começaram a ser pensados meios capazes de efetivar um sistema de controle que pudesse eliminar os excessos de governantes autoritários e ao mesmo tempo produzir equilíbrio no exercício do poder.

\subsection{A Liberdade de Expressão em Diplomas Internacionais}

A disciplina do direito fundamental à liberdade de expressão passou por um longo processo de afirmação histórica, o qual deu origem a diversos tratados internacionais, dentre os quais estão a Declaração Universal dos Direitos Humanos, de 1948, a Convenção Americana sobre Direitos Humanos, de 1969 e o Pacto Internacional sobre Direitos Civis e Políticos, de 1966, dos quais o Brasil é signatário. Apesar dos mecanismos diferenciados de impor suas disposições, o direito internacional, por vezes, pressiona os Estados signatários, ainda que soberanos, ao cumprimento do conteúdo pactuado. Há diplomas que, por sua vez, possuem natureza de recomendação, sem Con.

\footnotetext{
http://www.planalto.gov.br/ccivil_03/LEIS/L5250.htm. Acesso em 13 jul. 2018.)

25 Art. $1^{\circ}$ - omissis. Parágrafo único. Todo o poder emana do povo, que o exerce por meio de representantes eleitos ou diretamente, nos termos desta Constituição.
} 
A Declaração de Direitos, Bill of Rights de 1689, importante, entre outros aspectos, por colocar fim ao regime de monarquia absoluta na Inglaterra, não tinha como escopo a declaração de direitos humanos, mas propunha com a separação de poderes uma forma de organização do Estado que, em última análise, visava à proteção dos direitos fundamentais da pessoa humana ${ }^{26}$. Quanto ao exercício das liberdades, Comparato afirma que a Declaração de Direitos apresentava certa incoerência, pois, em suas palavras

se, de um lado, foi estabelecida pela primeira vez no Estado moderno a separação de poderes como garantia das liberdades civis, por outro lado essa fórmula de organização estatal, no Bill of Rights, constituiu o instrumento político de imposição, a todos os súditos do rei da Inglaterra, de uma religião oficial. ${ }^{27}$

Por outro lado, a Declaração Universal dos Direitos do Homem, proclamada em 1948, ainda sob o impacto da Segunda Guerra Mundial, prevê a proteção do livre exercício da liberdade de pensamento e expressão. $\mathrm{O}$ princípio da liberdade proclamado na Declaração abrange as dimensões individual e política, destacando-se, para efeitos de alcance deste trabalho, o âmbito individual ${ }^{28}$.

A criação dos Pactos Internacionais de Direitos Humanos objetivou desenvolver o conteúdo da Declaração de Direitos Humanos, com a institucionalização desses direitos em âmbito universal, assim como prever mecanismos de sanção a suas violações, através do Comitê de Direitos Humanos. O Pacto Internacional sobre Direitos Civis e Políticos, ao tratar da liberdade de expressão, prevê em seu artigo 19, que ninguém será privado de expor publicamente seu pensamento e opinião, não devendo ser molestado

\footnotetext{
${ }^{26}$ COMPARATO, 2015, p. 106.

${ }^{27}$ Ibid., p. 107.

${ }^{28}$ Artigo 18. Todo ser humano tem direito à liberdade de pensamento, consciência e religião; esse direito inclui a liberdade de mudar de religião ou crença e a liberdade de manifestar essa religião ou crença pelo ensino, pela prática, pelo culto em público ou em particular.

Artigo 19. Todo ser humano tem direito à liberdade de opinião e expressão; esse direito inclui a liberdade de, sem interferência, ter opiniões e de procurar, receber e transmitir informações e idéias por quaisquer meios e independentemente de fronteiras.

(Convenção Americana de Direitos Humanos. Costa Rica, 1969. Disponível em: https://www.cidh.oas.org/basicos/portugues/c.convencao_americana.htm. Acesso em 10 ago. 2018.)
} 
por essa razão, porém o $\$ 3^{\circ}$ aponta para a possibilidade de restrição desse direito em função do respeito à reputação de outras pessoas, assim como, a proteção da segurança nacional, a ordem, a saúde ou a moral públicas. Por oportuno, vale ressaltar que conceitos abertos como os mencionados no dispositivo devem ser casuisticamente analisados em consonância com o ordenamento jurídico pátrio.

Outro importante diploma internacional é a Convenção Americana de Direitos Humanos, da qual o Brasil, membro da OEA, também é signatário. Ela reproduz em grande medida disposições do Pacto Internacional de Direitos Civis e Políticos, prevendo o dever de respeito à liberdade de pensamento em suas diversas formas de expressão. Mas esse direito não está protegido ilimitadamente, suas disposições deixam clara a obrigação imposta ao Estado de criar leis com o objetivo de impedir a propagação de discurso de ódio, por exemplo ${ }^{29}$. Essa restrição, segundo a melhor doutrina, não se refere à liberdade de expressão pessoal, mas dirige-se à atividade empresarial no que tange a imprensa ${ }^{30}$.

O direito à liberdade de expressão aparece nesses documentos como um direito negativo, ou seja, ele não é provido pelo Estado, mas deve ser garantido por este. Isso quer dizer que o Estado é responsável pela efetivação desses direitos cabendo, inclusive, sanções no âmbito internacional em caso de descumprimento verificado.

O Tribunal Penal Internacional é o único organismo internacional capaz de condenar penalmente cidadãos responsáveis pela prática de crimes. O Estatuto que lhe regulamenta prevê sanção individualizada a quem seja

\footnotetext{
29 Art. 13.5 A lei deve proibir toda propaganda a favor da guerra, bem como toda apologia ao ódio nacional, racial ou religioso que constitua incitação à discriminação, à hostilidade, ao crime ou à violência.". (Convenção Americana de Direitos Humanos. Costa Rica, 1969. Disponível em: https://www.cidh.oas.org/basicos/portugues/c.convencao_americana.htm. Acesso em 10 ago. 2018.)

${ }^{30}$ Até a organização dos meios de comunicação em massa, o direito à liberdade de expressão era restrito aos que sabiam ler e escrever. A humanização da vida social decorrente do acesso a esse direito revela um verdadeiro avanço dos direitos humanos, já que para a autodeterminação humana, é imprescindível o acesso à informação adequada. Por outro lado, em consequência, há uma tendência dos conglomerados que dominam o mercado de comunicação ao uso do direito à liberdade de expressão como um direito à liberdade de exploração empresarial, o que não é factível.
} 
responsabilizado pelos chamados Crimes contra a Humanidade. Seu artigo $7^{\mathrm{o}}, \S 1^{\mathrm{o}}$, alínea b, prevê, entre os Crimes contra a Humanidade, a

Perseguição de um grupo ou coletividade que possa ser identificado, por motivos políticos, raciais, nacionais, étnicos, culturais, religiosos ou de gênero, tal como definido no parágrafo $3 \mathrm{o}$, ou em função de outros critérios universalmente reconhecidos como inaceitáveis no direito internacional, relacionados com qualquer ato referido neste parágrafo ou com qualquer crime da competência do Tribunal.

Nessa moldura, o direito internacional reconhece a prevalência da dignidade humana, caracterizando como Crime contra a Humanidade a perseguição de grupos por motivos raciais, políticos, religiosos etc., o que poderia ser caracterizado pela prática de discurso de ódio tamanho que suas consequências alcançassem proporções desmedidas.

Portanto, o direito internacional, em sua evolução, passou a reconhecer o direito à liberdade de expressão como uma forma de manifestação inerente à dignidade humana e claramente necessária ao pleno exercício de direitos humanos fundamentais.

\subsection{Liberdade de Expressão na Constituição Federal de 1988}

"A liberdade de expressão tem como objeto a manifestação de pensamentos, ideias, opiniões, crenças e juízos de valor." ${ }^{31}$ A afirmação da liberdade de expressão enquanto direito fundamental inaugura um período histórico relativamente recente. A proclamação desse direito como um direito subjetivo nasceu como estratégia de consolidação na transição do Antigo Regime para o Estado liberal.

No Brasil, a promulgação da Constituição de 1988 representou um marco no processo de redemocratização do Estado pós ditadura. Após experimentar momentos de grande restrição de direitos, sobretudo, com a

\footnotetext{
${ }^{31}$ FARIAS, Edilsom. Liberdade de Expressão e Comunicação. Teoria e proteção constitucional. São Paulo: Editora Revista dos Tribunais, 2004, p. 46
} 
edição dos Atos Institucionais após a Emenda Constitucional de 1969, o Brasil conquista uma Constituição digna de um país republicano.

Já sob a perspectiva de um Estado Democrático de Direito, a CRFB/88 se preocupou em definir direitos e garantias fundamentais, que, combinados com a previsão de direitos civis e políticos formaram o arcabouço necessário para a reestruturação do Estado brasileiro.

Tão logo superado esse momento de ausência constitucional, foi inaugurado o processo de redemocratização do Brasil; nele, pensar um país, cujos rumos seriam determinados pelo povo e em seu benefício volta a ser um objetivo realizável. O processo constituinte com a Assembleia de 1987/88 inaugurou a reconstitucionalização do Estado brasileiro.

Nesse processo de consolidação da democracia, a liberdade de expressão representou elemento fundamental. Conceber um Estado no qual a livre manifestação do pensar se tornava regra, onde a liberdade de expressar ideias e opiniões ganhava proteção constitucional foi uma das grandes façanhas da redemocratização.

Entre as discussões que embalaram a Constituinte, a maneira como se trataria a liberdade de expressão, e em que termos, marcou presença. Não é de se admirar que essa tenha sido uma preocupação, já que não se poderia admitir o retorno à censura em nenhuma hipótese.

A Constituição traz nos incisos IV, IX e XIV do artigo $5^{\circ}$ e no caput, parágrafos $1^{\circ}$ e $2^{\circ}$, do artigo 220 algumas disposições que bem demonstram seu compromisso com a instauração de uma nova ordem constitucional, na qual as liberdades representariam muito mais que um mero rabisco sem qualquer efetividade no seio da sociedade ${ }^{32}$.

\footnotetext{
32 Art. $5^{\circ}$ Todos são iguais perante a lei, sem distinção de qualquer natureza, garantindo-se aos brasileiros e aos estrangeiros residentes no País a inviolabilidade do direito à vida, à liberdade, à igualdade, à segurança e à propriedade, nos termos seguintes: IV - é livre a manifestação do pensamento, sendo vedado o anonimato; VI - é inviolável a liberdade de consciência e de crença, sendo assegurado o livre exercício dos cultos religiosos e garantida, na forma da lei, a proteção aos locais de culto e a suas liturgias;
} 
Tais dispositivos relacionados ao direito de liberdade de expressão do pensamento; liberdade de consciência e crença; liberdade de expressão da atividade intelectual, artística, científica e de comunicação; de acesso à informação; do direito de resposta e da liberdade de aprendizado e ensino constituem uma série de direitos e liberdades fundamentais com conteúdo e âmbitos de aplicação distintos, os quais podem ser agrupados sob a denominação "liberdade de expressão". Apesar de autônomos tais direitos e liberdades dialogam entre si. Pode-se dizer que tais disposições representam respostas ao trauma vivenciado durante a ditadura militar e o autoritarismo que permeou aquele período da história, com vistas a não permitir que tais acontecimentos se repitam.

O texto que resulta dos projetos da constituinte veda qualquer tipo de censura e garante que ninguém seja punido pelo simples fato de expressar seu pensamento. Logo, é garantido ao indivíduo que se manifeste, no exercício da liberdade garantida, sendo vedado o anonimato. Essa vedação ao anonimato denota a clara preocupação do constituinte em evitar abusos no exercício do direito.

$\mathrm{O}$ tratamento privilegiado conferido à liberdade de expressão pela CRFB/88 garantiu sua abrangência. Isto porquê o direito à liberdade de expressão pode ser concebido sob três dimensões: em sua dimensão individual, representa um direito essencial à dignidade humana; em sua dimensão coletiva, constitui um instrumento para a busca da verdade; e em

IX - é livre a expressão da atividade intelectual, artística, científica e de comunicação, independentemente de censura ou licença;

XIV - é assegurado a todos o acesso à informação e resguardado o sigilo da fonte, quando necessário ao exercício profissional;

XXXIII - todos têm direito a receber dos órgãos públicos informações de seu interesse particular, ou de interesse coletivo ou geral, que serão prestadas no prazo da lei, sob pena de responsabilidade, ressalvadas aquelas cujo sigilo seja imprescindível à segurança da sociedade e do Estado;

Art. 220. A manifestação do pensamento, a criação, a expressão e a informação, sob qualquer forma, processo ou veículo não sofrerão qualquer restrição, observado o disposto nesta Constituição.

$\S 1^{\circ}$ Nenhuma lei conterá dispositivo que possa constituir embaraço à plena liberdade de informação jornalística em qualquer veículo de comunicação social, observado o disposto no art. $5^{\circ}, \mathrm{IV}, \mathrm{V}, \mathrm{X}$, XIII e XIV.

$\S 2^{\circ}$ É vedada toda e qualquer censura de natureza política, ideológica e artística.

(Constituição da República Federativa do Brasil. Art. $5^{\circ}$.

BRASIL. Constituição (1988). Acesso em 15 ago. 2018) 
sua dimensão política, corresponde a um elemento indispensável para a manutenção da democracia e autogoverno.

Logo, são plenamente compreensíveis os esforços da Constituição Federal em proteger a liberdade de expressão, cabendo aos poderes constituídos a efetiva realização desse direito pelas instituições públicas.

\subsection{Possibilidade de Mitigação/Restrição do Exercício da Liberdade de Expressão}

Ao longo da história da humanidade, muitos foram os questionamentos de cunho moral que se evidenciaram e tiveram claro efeito sobre o direito. De modo que, não raramente, argumentos morais legitimaram e continuam legitimando perigosas restrições de direitos ${ }^{33}$.

Os direitos fundamentais constituem base interpretativa do texto constitucional, cabendo-lhes, ainda, nortear a aplicação de tais normas. As normas extraídas dos enunciados de direitos fundamentais podem, não raramente, configurar hipóteses de princípios constitucionais. ${ }^{34}$

Segundo Robert Alexy, os princípios são normas que devem ser realizadas na maior medida possível, dentro das possibilidades jurídicas e reais existentes. Nesse sentido, não se pode garantir a efetivação irrestrita sequer de um princípio constitucional, cuja carga valorativa nos remete a um preceito fundamental e nuclear do ordenamento jurídico. Alexy defende que os princípios são comandos de otimização, que se caracterizam por poderem ser cumpridos em diferentes graus, considerando que a medida devida de seu

\footnotetext{
${ }^{33}$ Diante de uma análise sobre liberdade e moralismo, ao refutar os argumentos que lorde Devlin usa para justificar a criminalização da homossexualidade, Dworkin afirma que o fato de determinada prática ser moralmente condenável para a maioria da sociedade não impõe sua criminalização, já que não representa qualquer ameaça à existência da sociedade. Além disso, ele afirma que é equivocado extrair o direito penal da moralidade pública, pois as práticas morais da sociedade são altamente complexas.

${ }^{34}$ ALEXY, 2014, p. 63.
} 
cumprimento não só depende das possibilidades reais, mas também das possibilidades jurídicas. ${ }^{35}$

Logo, é possível depreender desse entendimento que nem sempre o princípio terá aplicação prevalente, considerando determinada situação fática. Tendo em vista que os princípios fundamentais devem ser protegidos maximamente, pode-se dizer que uma norma só pode ser restritiva de um direito fundamental se se tratar de uma norma constitucional, caso contrário, tratar-se-ia de mera intervenção ${ }^{36}$.

A liberdade negativa em sentido estrito ${ }^{37}$ é aquela liberdade liberal, a liberdade de fazer ou não fazer alguma coisa. Trata-se da liberdade jurídica que conhecemos, a liberdade, conteúdo do princípio da legalidade que prevê que "ninguém será obrigado a fazer ou deixar de fazer alguma coisa senão em virtude de lei" 38 . Não obstante, a liberdade negativa em sentido amplo vai mais além e tem como conteúdo um conceito mais amplo de liberdade, ela abarca a liberdade socioeconômica, que não existe quando situações deficitárias impeçam o exercício da liberdade, através de determinadas ações.

O princípio objeto deste trabalho diz respeito à liberdade negativa de ação ou liberdade jurídica, a qual pressupõe que as alternativas de ação sejam minimamente afetadas por proibições e ordenanças por parte do Estado. Assim, tudo que afetar a realização do princípio pode ser submetido a uma análise de utilidade e necessidade. Um dos grandes problemas que surgem dessa afetação dos princípios em geral, inclusive o da liberdade, é a

\footnotetext{
35 "Por lo tanto, los princípios son mandatos de optimización, que se caracterizan porque pueden cumplirse en diferente grado y que la medida debida de su cumplimiento no sólo depende de las possibilidades reales sino también de las possibilidades jurídicas." (ALEXY, 2014, p. 68).

${ }^{36}$ ALEXY, 2014, p. 244.

${ }^{37}$ Ibid., p. 308.

${ }^{38}$ Constituição da República Federativa do Brasil.

BRASIL. Constituição (1988). Art. $5^{\circ}$, II.

Disponível em: http://www.planalto.gov.br/ccivil_03/constituicao/constituicaocompilado.htm Acesso em 22 ago. 2018.
} 
ponderação. A intensidade da afetação da liberdade deve se justificar por razões proporcionais a essa intensidade ${ }^{39}$.

Há um reconhecido perigo de que restrições à liberdade de expressão não se justifiquem como destinadas à garantia da segurança ou criação de liberdades de valor mais elevado em relação a um ou outro direito fundamental. Ronald Dworkin afirma que a restrição de qualquer liberdade, inclusive a livre manifestação do pensamento, por parte do Estado deve se sujeitar a uma análise casuística que propicie a indicação da medida em que o direito deve ser protegido ou restringido ${ }^{40}$. Dworkin diz que "a retórica da liberdade alimenta todos os movimentos radicais" e, nesse sentido, evidencia-se a necessidade de compreensão da origem das reivindicações em torno do direito à liberdade, evitando que a radicalização o anule por completo.

A tradicional definição de liberdade pressupõe ausência de restrições determinadas pelo Estado sobre a ação voluntária de homens e mulheres, esse é o conceito de liberdade como licença. Para o pensamento liberal, qualquer restrição na liberdade deve ser maximamente evitada.

Muitos dos argumentos que defendem a limitação do direito à liberdade estão apoiados na teoria utilitarista de Jeremy Benthan. Assim, as leis que restringem a liberdade atendem ao interesse ou o bem-estar geral,

\footnotetext{
${ }^{39}$ Alexy utiliza os exemplos do homem que alimenta pombos e aquele que assiste a cultos religiosos, questionando se do ponto de vista da afetação da liberdade, ambos são afetados no mesmo grau. Ele afirma que não é possível mensurar a afetação em si. Para ele, a possibilidade de proibição de uma ação em todas as suas formas é realmente muito intensa. E, portanto, as restrições podem ser impostas na medida em que se exigir o caso concreto.

40 "Sem dúvida, um governo responsável deve estar pronto para justificar o que quer que faça, particularmente quando isso restringe a liberdade de seus cidadãos. Em geral, porém, é uma justificação suficiente, mesmo para um ato que limita a liberdade, que esse ato seja calculado de modo que aumente aquilo que os filósofos chamam de utilidade geral - ou seja, calculado de modo que, no cômputo geral, produza mais benefícios do que danos (...) embora os cidadãos tenham direito à liberdade de expressão, o governo pode ignorar esse direito quando necessário para proteger os direitos de outros, ou para evitar uma catástrofe, ou mesmo para obter um benefício público mais evidente e importante" (DWORKIN, Ronald. Levando os direitos a sério. Tradução Nelson Boeira. $3^{\mathrm{a}}$ ed. São Paulo: Editora WMF Martins Fontes, 2010, p.294).
} 
todavia não são ilimitadas, mas devem atender um elevado grau de necessidade imposta por grave violação de outro direito fundamental ${ }^{41}$.

Faz-se mister ressaltar, nesse sentido, que a restrição é admitida, sim, nos casos em que se exija para proteger direito fundamental igualmente violado, que, por sua vez, possua maior grau de dano. É consentâneo o entendimento de que a censura prévia, em regra, não deve existir em uma sociedade democrática, mas não há que dizer de um direito absoluto. Nas palavras de Comparato:

Juridicamente falando, a liberdade é a ausência de proibições ou autorizações prévias, para a prática de atos ou o exercício de uma atividade profissional. A liberdade de expressão é incompatível com o estabelecimento de censura prévia, de qualquer natureza - política, moral ou religiosa - para os espetáculos públicos ou meios de comunicação de massa. O que não significa que possa ser tolerada uma liberdade irresponsável. Ao contrário, todo abuso deve ser reprimido, pois significa a negação do direito ${ }^{42}$.

A limitação da liberdade de expressão é consequência necessária da aplicação do direito, i.e. existem direitos outros que confrontados ao livre pensamento e expressão de ideias, mostram-se prevalentes. Esse juízo cabe ao Poder Judiciário, que é responsável por dizer o que prevalece no caso concreto. A esse respeito, Fábio Leite aduz que:

A restrição imposta pelo Poder Judiciário, no entanto, não é compreendida como um problema sequer semelhante ao que decorre da censura. E isso, por uma série de razões: (i) nestes casos é assegurada a liberdade de expressão, na medida em que não há censura prévia; (ii) a liberdade de expressão não é nem poderia ser um direito absoluto; (iii) a Constituição protege outros valores, como a honra, a imagem, a vida privada e a intimidade (art. $5^{\circ}, \mathrm{X}$ ); (iv) cabe ao Poder Judiciário a função justamente de dirimir uma lide, dizendo o direito num caso concreto; (v) a própria Constituição, após estabelecer que "é livre a manifestação do pensamento", assegurou, como contrapartida, não apenas o "direito de resposta, proporcional ao

\footnotetext{
${ }^{41}$ Dworkin apresenta sua teoria acerca da possibilidade de restrição nos seguintes termos: "Ela não pretenderia defender a existência de um direito a toda liberdade, mas simplesmente às liberdades básicas e importantes. Como Benthan disse, toda lei é uma violação da liberdade, mas só temos o direito de nos proteger contra as violações graves ou fundamentais. Nos casos em que a restrição à liberdade for suficientemente grave ou severa, é verdadeiro afirmar que o governo não está autorizado a impor essa restrição, apenas porque ela seria imposta no interesse geral.” (Ibid., p. 415) ${ }^{42}$ COMPARATO, 2015, p. 150.
} 
agravo", como a possibilidade de indenização por dano material, moral ou à imagem ${ }^{43}$.

${ }^{43}$ LEITE, Fábio Carvalho. Liberdade de Expressão e Direito à Honra: Novas Diretrizes para um Velho Problema. apud CLÈVE, Clèmerson Merlin; FREIRE, Alexandre (Org.). Direitos fundamentais e Jurisdição Constitucional: Análise, Crítica e Contribuições. $1^{a}$ ed. São Paulo: Revista dos Tribunais, 2014. p. 395-408. 


\section{CAPÍTULO 3 - LIBERDADE X IGUALDADE: O PAPEL REGULATÓRIO DO ESTADO}

\subsection{Colisão Entre Normas Constitucionais: Técnica da Ponderação Como Limitador}

Diante de um ordenamento jurídico complexo, cujo norte centra-se na figura da Constituição Federal, a tarefa do intérprete constitucional tem se tornado cada vez mais difícil. Isso ocorre, sobretudo, porque a adoção de conceitos indeterminados e o uso de cláusulas gerais na criação das normas jurídicas faz com que as prescrições legais tenham alcance mais amplo e normativas menos específicas no decorrer do tempo. As intensas mudanças sociais são as responsáveis por esse movimento, que exige cada vez mais dos operadores do direito.

Em face dos conceitos indeterminados, o papel do juiz passa a apresentar um caráter integrativo. Ou seja, lhe é atribuído o dever de complementar a norma a partir de sua valoração, considerando que não pode deixar de decidir no caso concreto ${ }^{44}$. A teoria dos casos difíceis assevera que mesmo quando nenhuma regra regula o caso, uma das partes pode ter o direito de ganhar a causa. O juiz continua tendo o dever, mesmo nos casos difíceis, de descobrir quais são os direitos das partes, e não de inventar novos direitos retroativamente.

Por força do princípio da unidade da constituição, não há que se falar em hierarquia jurídica entre normas constitucionais. Os direitos fundamentais, por sua vez, ocupam na ordem constitucional vigente a posição de cláusulas pétreas. Portanto, não se pode conceber uma regra abstrata que determine a prevalência de um direito sobre o outro.

\footnotetext{
${ }^{44} \mathrm{O}$ mandamento constitucional insculpido no art. $5^{\circ}, \mathrm{XXXV}$, assegura que "a lei não excluirá da apreciação do Poder Judiciário lesão ou ameaça a direito". O Código de Processo Civil, ao regulamentá-lo, preceitua em seu art. $3^{\circ}$ que "Não se excluirá da apreciação jurisdicional ameaça ou lesão a direito." E no art. 140, mais especificamente, que "O juiz não se exime de decidir sob a alegação de lacuna ou obscuridade do ordenamento jurídico."
} 
Em virtude das dificuldades enfrentadas nesse sentido, os Tribunais Superiores vêm adotando a ponderação como método de solução de casos difíceis ("hard cases"), em relação aos quais a subsunção não se mostra adequada e suficiente. $\mathrm{O}$ uso da ponderação está diretamente ligado a situações em que há confronto de razões, valores ou interesses albergados pela Constituição ${ }^{45}$. Sob esse ângulo de mirada, percebe-se que o uso da ponderação depende de uma colisão substancial que envolva princípios constitucionais com conteúdo dotado de alto grau de essencialidade e, portanto, merecedores de tutela efetiva. Importante salientar que o esforço de aplicação dos princípios na maior medida possível diante de complexos casos concretos tem como objetivo central a manutenção da unidade da Constituição.

A ponderação apresenta-se como um processo dividido em três etapas: (i) na primeira fase, são identificadas as normas em conflito; (ii) na segunda fase, são examinadas as circunstâncias do caso concreto e suas repercussões sobre os elementos normativos; (iii) na terceira fase, são examinados os grupos de interesses em disputa e o impacto das normas sobre os fatos, de modo que se possa aferir os pesos atribuídos aos elementos em disputa, que serão considerados para a solução do caso. A distribuição de pesos é o diferencial no método da ponderação, pois faz com que se chegue ao grupo de normas que deve prevalecer no caso concreto ${ }^{46}$.

\footnotetext{
${ }^{45} \mathrm{O}$ propósito da ponderação é solucionar esses conflitos normativos da maneira menos traumática para o sistema como um todo, de modo que as normas em oposição continuem a conviver, sem a negação de qualquer delas, ainda que em determinado caso concreto elas possam ser aplicadas em intensidades diferentes. A ponderação também se presta a organizar o raciocínio e a argumentação diante de situações nas quais, a despeito do esforço do intérprete, haverá inevitavelmente uma ruptura do sistema e disposições normativas válidas terão sua aplicação negada em casos específicos. (BARCELLOS, Ana Paula de. Alguns parâmetros normativos para a ponderação constitucional apud BARROSO, Luís Roberto. A nova interpretação constitucional: ponderação, direitos fundamentais e relações privadas. $3^{\mathrm{a}}$ ed. Rio de Janeiro: Renovar, 2008. p. 57).

${ }^{46}$ A ponderação consiste, portanto, em uma técnica de decisão jurídica aplicável a casos difíceis, em relação às quais a subsunção se mostrou insuficiente, sobretudo quando uma situação concreta dá ensejo à aplicação de normas de mesma hierarquia que indicam soluções diferenciadas. (BARROSO, Luis Roberto. Colisão entre liberdade de expressão e direitos da personalidade. Critérios de ponderação. Interpretação constitucionalmente adequada do código civil e da lei de imprensa. p. 114-115).
} 
Para facilitar a compreensão e aplicação do método é necessário traçar a distinção entre a ponderação feita em abstrato e a realizada em concreto. A ponderação em abstrato é caracterizada pela criação de parâmetros de solução de conflitos pensadas em tese pela doutrina. Esses critérios servem de modelo de solução ao intérprete, que, diante do caso, farão uso dos parâmetros gerais e específicos. Já a ponderação em concreto é demandada quando esses indicadores são insuficientes para solver o caso em questão. $\mathrm{Na}$ hipótese, exige-se uma ponderação particular, feita sob medida para o caso concreto, o qual fornece subsídios para aplicação dos pesos que permitirão a construção da norma adequada ao caso ${ }^{47}$.

O exame de proporcionalidade é usado para estruturar a ponderação judicial, mas não é suficiente para que se alcance um padrão aceitável de racionalidade. Deve-se, todavia, somar a este, o emprego de jurisprudência relativa ao direito envolvido, eleição de padrões de controle, assim como, formulação de parâmetros gerais e específicos, que servirão a ponderações futuras, são os chamados standards de proteção.

Para que a ponderação seja efetivada, é necessário que o intérprete identifique o conteúdo mínimo dos direitos envolvidos no conflito normativo. Esse conteúdo mínimo deriva da garantia do núcleo essencial dos direitos fundamentais, o qual estabelece um espaço material irrestringível que circunda o direito fundamental, protegendo-o da atuação legislativa. Concebido como o "limite dos limites", esse âmbito de proteção auxilia no processo hermenêutico aplicativo dos direitos fundamentais e atua como um padrão jurídico racionalizador da ponderação ${ }^{48}$.

\footnotetext{
47“"Por natural, para que a ponderação em concreto possa alimentar a ponderação em abstrato de informações é preciso que as soluções adotadas em cada caso possam ser universalizadas." (BARCELLOS, Ana Paula de. Alguns parâmetros normativos para a ponderação constitucional. In: BARROSO, Luís Roberto (Org.). A nova interpretação constitucional: ponderação, direitos fundamentais e relações privadas. $3^{\mathrm{a}}$ ed. Rio de Janeiro: Renovar, 2008. p. 66)

${ }^{48}$ ALMEIDA, Luiz Antônio Freitas de. Direitos fundamentais sociais e ponderação: ativismo irrefletido e controle jurídico racional / Luiz Antônio Freitas de Almeida. - Porto Alegre: Sergio Antonio Fabris Ed., 2014.
} 
Tratando-se de liberdade de expressão e direito à intimidade, fala-se de dois princípios constantes da própria Constituição Federal. Logo, não se cogita de uma tarefa simples a determinação do âmbito de incidência das normas ${ }^{49}$ em conflito.

Segundo Alexy, o âmbito de proteção em sentido amplo engloba o âmbito de proteção em sentido estrito e a intervenção estatal incidente sobre o bem jurídico. De modo que, o âmbito de proteção em sentido amplo inclui em seu conteúdo tudo o que for suficiente para tipificar a norma de direito fundamental, assim como a interpretação ampla dos conceitos de suporte do direito fundamental, de forma a independer de valorações para afastar uma situação à subsunção desses conceitos.

Nesse sentido, salta aos olhos a importância da interpretação no processo ponderativo, já que mesmo em face da amplitude do âmbito de proteção dos direitos considerados, a interpretação é necessária e fundamental para a concretização da ponderação em sua forma mais eficaz.

\footnotetext{
${ }^{49} \mathrm{O}$ primeiro passo metodológico é reconhecer que os direitos fundamentais são outorgados por normas jurídicas que possuem essencialmente o caráter de princípios. Aqui cobra importância a distinção estrutural entre princípios e regras. A distinção entre princípios e regras reside mormente no fato de que os princípios "não expressam consequiências jurídicas que se seguem automaticamente quando se dão as condições previstas". Ao revés, as regras são aplicadas à feição de "de tudo ou nada", isto é, "se ocorrerem os fatos estabelecidos por uma regra, então: ou a regra é válida, e, em tal caso, deve-se aceitar a resposta que ela oferece; ou a regra é inválida, e, em tal caso, não influi na decisão". Noutras palavras, em sendo válidas, as regras são normas jurídicas que devem ser cumpridas de forma peremptória, sem admitir graduação; por sua vez, os princípios são normas jurídicas que prescrevem algo para ser efetivado da melhor forma possível, tendo em conta as possibilidades fáticas e jurídicas. Em suma, os princípios são mandados de otimização que se caracterizam pelo fato de poderem ser cumpridos proporcionalmente às condições reais e jurídicas existentes. A diferença lógica entre princípios e regras implica uma outra muito importante. Os princípios possuem uma dimensão do peso ou da importância ausentes nas regras. Essa característica revela-se claramente quando dois ou mais princípios entram em conflito entre si. Nessa hipótese, a colisão será solucionada levando-se em conta o peso ou a importância relativa de cada princípio, a fim de escolher quais deles no caso concreto prevalecerão ou sofrerão menos constrição do que os outros. Contudo, os princípios preteridos na colisão não deverão ser declarados inválidos, senão que, sob determinadas condições, um princípio tem mais peso ou importância do que outro e em outras circunstâncias poderá ocorrer o inverso. No caso de conflito de regras apenas uma delas poderá ser válida, cumprindo ao intérprete identificar qual a válida. Para essa decisão o operador do direito será orientado por critérios tais como lex superior derogat inferiori, lex posteriori derogat priori e lex specialis derogat generali. Corolário natural do anteriormente assinalado é que os parâmetros utilizados para resolver a colisão de princípios poderão ser aplicados na colisão de direitos fundamentais. Esses cânones hermenêuticos são, dentre outros, o princípio da unidade da constituição, da concordância prática e da proporcionalidade. (FARIAS, 2004, p.39-40).
} 


\subsection{As Peculiaridades do Caso Concreto Como Critério de Prevalência do Direito Fundamental: Jurisprudência Brasileira}

Os direitos da personalidade, conforme amplamente difundido na doutrina, são divididos em dois grandes grupos: (i) os direitos à integridade física, que abarcam o direito à vida, ao próprio corpo e o direito ao cadáver e; (ii) direitos à integridade moral, no qual estão inseridos o direito à honra, liberdade, à vida privada, à intimidade, à imagem, entre outros.

A dignidade da pessoa humana constitui fundamento da República Federativa do Brasil ${ }^{50}$ e irradia seus efeitos sobre todo o ordenamento jurídico. Esse princípio aponta para a centralidade da figura do ser humano como sujeito à proteção do Estado sem qualquer distinção. Portanto, a Constituição promove a tutela da personalidade, sob a égide da dignidade humana, em uma série de dispositivos que apontam para essa proteção ${ }^{51}$

É bem de ver que a intimidade e a vida privada são noções que estão contidas no conceito de direito à privacidade, cujo conteúdo indica o reconhecimento de uma esfera de proteção face a curiosidade de terceiros particulares. Esse espectro abrange as escolhas pessoais, as relações afetivas, atitudes e até comentários em conversas privadas. Quando se falava de sujeitos sem projeção pública, geralmente, não havia interesse nesse tipo de informação, porém sujeitos expostos à vida pública tendiam a atrair olhares curiosos resultado da auto exposição. Atualmente, com a rápida expansão das

\footnotetext{
${ }^{50}$ Constituição da República Federativa do Brasil. BRASIL Constituição (1988) Art. 1º, III.

Disponível em: http://www.planalto.gov.br/ccivil_03/constituicao/constituicaocompilado.htm. Acesso em 15 out. 2018.

${ }^{51}$ Art. $5^{\circ}(\ldots)$

V - é assegurado o direito de resposta, proporcional ao agravo, além da indenização por dano material, moral ou à imagem;

(...)

$\mathrm{X}$ - são invioláveis a intimidade, a vida privada, a honra e a imagem das pessoas, assegurado o direito a indenização pelo dano material ou moral decorrente de sua violação; (Constituição da República Federativa do Brasil.

BRASIL Constituição (1988) Art. $1^{\circ}$, III.

Disponível em: http://www.planalto.gov.br/ccivil_03/constituicao/constituicaocompilado.htm. Acesso em 15 out. 2018.)
} 
novas tecnologias e o alcance cada vez maior das mídias sociais, esse quadro pode ser questionado, já que pessoas comuns têm se sujeitado a exibição de suas vidas privadas como forma de manter e alimentar relações sociais, saindo do anonimato em razão disso.

Não ofende a privacidade a divulgação de informações que já alcançaram o domínio público, sobretudo por meio de veículos de comunicação em massa. A jurisprudência já se debruçou sobre a questão das biografias não autorizadas na $\operatorname{ADI} 4815^{52}$, na qual o Supremo Tribunal Federal proferiu acórdão atribuindo interpretação conforme a constituição aos artigos 20 e 21 do Código Civil para declarar inexigível autorização de pessoa biografada no que tange a obras biográficas, literárias ou audiovisuais, sendo também desnecessária autorização de pessoas retratadas como coadjuvantes ou de seus familiares, em caso de pessoas falecidas ou ausentes.

Sob esse ângulo, a decisão foi enfática ao mencionar a proibição de censura prévia de qualquer natureza para justificar a impossibilidade de restrição do direito à liberdade de expressão e o direito à informação. Importante destacar a preocupação dos ministros em afirmar que eventual violação do direito à intimidade ou à honra deve ser indenizada nos termos da lei. O ministro Luís Roberto Barroso destacou que o Código Civil ponderou a tensão dos direitos em desfavor da liberdade de expressão, que, segundo ele, tem posição preferencial dentro do sistema constitucional. Ressaltou que essa posição decorre tanto do texto constitucional como do histórico brasileiro de censura a jornais, revistas e obras artísticas, que perdurou até a última ditadura militar.

\footnotetext{
${ }^{52}$ Autorização prévia para biografia constitui censura prévia particular. O recolhimento de obras é censura judicial, a substituir a administrativa. O risco é próprio do viver. Erros corrigem-se segundo o direito, não se cortando liberdades conquistadas. A reparação de danos e o direito de resposta devem ser exercidos nos termos da lei. 7. A liberdade é constitucionalmente garantida, não se podendo anular por outra norma constitucional (inc. IV do art. 60), menos ainda por norma de hierarquia inferior (lei civil), ainda que sob o argumento de se estar a resguardar e proteger outro direito constitucionalmente assegurado, qual seja, o da inviolabilidade do direito à intimidade, à privacidade, à honra e à imagem. (STF, ADI 4.815/DF. Rel. Min. Carmen Lúcia, Brasília, 16 fev. 2016.)
} 
O caso das biografias constitui hipótese particular de manifestação da liberdade de expressão, pois está diretamente ligado à História. O interesse em garantir a publicação das biografias empreende-se no esforço de impedir a obstrução da criação de memória, segundo o interesse coletivo. Todavia, outra importante decisão do STF asseverou que o direito à liberdade de expressão não é capaz de proteger manifestações de cunho racista.

No emblemático julgamento do Habeas Corpus $82424^{53}$, apontado pela doutrina como o julgamento mais importante da Corte Suprema em matéria de Direitos Humanos, o STF, por maioria, negou o pedido de Siegfried Ellwanger, condenado por racismo. Essa decisão teve ampla aquiescência tanto de juristas quanto da sociedade civil e demonstrou o forte consenso no que diz respeito ao não reconhecimento de proteção constitucional ao hate speech ${ }^{54}$.

“O Estado, que, com os direitos fundamentais, assegura a liberdade do cidadão não pode retirar essa liberdade com a simples aplicação do princípio da igualdade. O engajamento político e religioso integra o livre exercício do direito de propriedade e o livre exercício do direito de desenvolvimento da personalidade. A liberdade de testar é integrada pela liberdade de diferençar por motivos políticos ou religiosos." 55

\subsection{Análise da Liberdade de Expressão e Discurso de Ódio nos EUA}

\subsubsection{Hate speech e a Primeira Emenda norte-americana: posição da Suprema Corte}

A expansão na proteção da liberdade de expressão nos Estados Unidos tem se dado em parte sob o custo de um enfraquecimento na garantia de

\footnotetext{
${ }^{53}$ STF. HC 82424-2/RS. Rel. Ministro Moreira Alves. Brasília, 19 mar. 2004.

${ }^{54}$ Nas palavras de Gilmar Mendes: "não se pode atribuir primazia à liberdade de expressão, no contexto de uma sociedade pluralista, em face de valores outros como os da igualdade e da dignidade humana"

${ }^{55}$ STF. RE 201819/RJ, Rel. Min. Ellen Gracie, Rel. p/ acórdão Min. Gilmar Mendes, Brasília, 27 out. 2006.
} 
outros direitos contrapostos, como o direito à privacidade, à honra e à igualdade. Nesse contexto, formou-se jurisprudência firme no sentido da proteção constitucional de diversas manifestações de ódio e intolerância contra minorias.

Uma delas foi proferida no julgamento do caso Brandemburg vs. Ohio, em 1969. Nesse caso, a Suprema Corte reformou decisão que condenara Brandemburg, um líder da Ku Klux Klan no Estado de Ohio, pelo delito de apologia ao crime (criminal syndicalism). Este havia organizado e promovido um encontro da entidade. Imagens do evento foram transmitidas ao público, pela televisão, por um repórter convidado. As imagens continham pessoas encapuzadas queimando cruzes e proferindo palavras de ordem contra negros e judeus. Durante a manifestação, Brandemburg, no uso da palavra, disse que "os nigger (expressão altamente ofensiva usada para se referir aos negros de forma pejorativa) deveriam ser devolvidos para a África e os judeus para Israel”.

A decisão da Suprema Corte entendeu que a lei do estado de Ohio punia a simples defesa de uma ideia, o que seria totalmente incompatível com a liberdade de expressão. A tese defendida pela Corte distinguiu a defesa de ideias racistas, cujo conteúdo está protegido pela liberdade de expressão da incitação à prática de atos violentos, que não está protegida. O que ratificou o entendimento que há muito se perpetua no seio da jurisprudência norteamericana, a defesa irrestrita da liberdade de expressão.

De fato, a jurisprudência norte-americana assume posição de defesa quase incondicional do hate speech. $\mathrm{O}$ que permite que se aponte, por exemplo, para uma valorização maior da liberdade em relação à igualdade na tradição do constitucionalismo e da própria cultura norte-americana, que se expressa na fragilidade da segurança social existente no país, sobretudo 
quando confrontada com a sua potência econômica, assim como na rejeição da ideia de direitos sociais e econômicos ${ }^{56}$.

No que tange à própria liberdade, há predominância no pensamento jurídico norte-americano de uma concepção tão formal desse valor que ignora a opressão real exercida sobre sujeitos de direito. Ou seja, para favorecer o exercício da autonomia individual presente nas próprias estruturas sociais, esta visão empobrece a liberdade, ao equipará-la à mera ausência de coação estatal sobre os indivíduos. Em matéria de liberdade de expressão, ela ignora a força silenciadora que o discurso opressivo dos intolerantes pode exercer sobre os seus alvos.

\subsubsection{Regulação do Discurso de Ódio a Partir da Experiência Norte- americana}

A importância da regulamentação do discurso de ódio tem como escopo a promoção dos mesmos valores deliberativos que expliquem a proibição da censura. Para a doutrina norte americana, que há muito se debruça sobre questões relativas ao exercício da Liberdade de Expressão, o discurso do ódio representa uma subcategoria do discurso discriminatório. Ou seja, seu conteúdo defende o que é de baixo valor e danoso.

Entende-se que as restrições sobre a liberdade são permitidas se decorrerem da aplicação do Princípio do Dano, o qual preceitua que deve haver um dano ou ameaça iminente de dano para que se justifique a restrição do exercício à liberdade de expressão. Ocorre que muitas vezes o conceito de dano não toma contornos claros a ponto de ensejar qualquer responsabilização.

\footnotetext{
${ }^{56}$ SARMENTO, Daniel. A liberdade de expressão e o problema do "hate speech". Disponível em: http://www.dsarmento.adv.br/content/3-publicacoes/19-a-liberdade-de-expressao-e-o-problemado-hate-speech/a-liberdade-de-expressao-e-o-problema-do-hate-speech-daniel-sarmento.pdf. Acesso em 19 out. 2018.
} 
A Primeira Emenda norte-americana sujeita-se a duas teorias interpretativas: uma libertária e a outra democrática. A Teoria libertária defende que a Primeira Emenda representa uma proteção da auto expressão, o que denota individualismo na expressão do direito. Essa teoria direciona as atenções ao autor da mensagem. E assim, entende que as garantias da Primeira Emenda visam a proteção da autonomia privada, assim como o direito de expressar pensamentos de forma livre. Por outro lado, a Teoria democrática enxerga a Primeira Emenda como um instrumento de autogoverno. Essa Teoria defende que ela deve ser capaz de garantir que os cidadãos sejam livres para fazerem suas escolhas após a formação de seu convencimento, após uso das informações necessárias para tanto. Essa teoria localiza o destinatário da mensagem no centro do debate. E por isso mesmo, acredita na realização de um processo coletivo de tomada de decisões na esfera pública ${ }^{57}$.

A primeira Teoria acredita que o Estado deve limitar-se a proteger os direitos do emissor, enquanto a segunda vê na Primeira Emenda a finalidade de assegurar a liberdade política dos cidadãos.

Diante de tais esclarecimentos, faz-se mister destacar a atuação do Estado na aplicação de ambas as teorias. Enquanto, a teoria libertária defende atuação negativa do Estado no intuito de impedir que este silencie os cidadãos, a teoria democrática supera a ideia de que o Estado representa o inimigo natural da liberdade e lhe confere o encargo de atuar para garantir a efetiva realização deste direito por todos os cidadãos.

O grande problema da interpretação libertária é que, em última análise, o discurso será controlado pela grande mídia, já que as forças do mercado teriam maior influência sobre a disseminação de informações. Ao passo que, a teoria democrática poderia gerar temor em relação à censura,

\footnotetext{
${ }^{57}$ FISS, Owen M. A Ironia da Liberdade de Expressão. Trad. Gustavo Binenbojm e Caio Mário da Silva Pereira Neto. Rio de Janeiro: Renovar, 2005, p. 75.
} 
considerando que a regulação do conteúdo poderia resultar em mal maior que a manifestação das forças do mercado.

Nesse contexto, surgem questionamentos como: até que ponto o direito à liberdade de expressão deve ser protegido? Ou mesmo, vale a pena restringir um direito fundamental tão caro à democracia?

Vejamos. É no mínimo perigoso pensar a possibilidade de silenciar determinado tipo de discurso com base em conveniência. Isto porquê argumentos como a utilidade ou a conveniência são claramente insuficientes para justificar a limitação do exercício de um direito fundamental, tal qual a liberdade de pensamento e manifestação. Portanto, entende-se que o tema carece de profundas discussões.

A capacidade intelectual de um indivíduo inclui suas capacidades deliberativas. Nesse sentido, é possível afirmar que as liberdades de pensamento e discussão são tão importantes quanto necessárias para justificar as crenças e ações dos indivíduos. Assim, o autogoverno pressupõe uma educação capaz de desenvolver capacidades deliberativas.

Contribuindo com a formação da capacidade deliberativa dos cidadãos está o acesso adequado ao conteúdo informativo de diferentes discursos. Isso quer dizer que, para a manutenção de uma democracia saudável, é necessário que todos tenham condições e acesso a informação suficiente para basear as escolhas que determinarão os rumos da sociedade.

Nesse diapasão, é conveniente traçarmos a diferença entre duas importantes concepções: os discursos de alto e baixo valor.

O discurso de alto valor é aquele que coopera para o enriquecimento da discussão e traz ideias a serem consideradas na formação de um debate amplo e plural. O discurso de alto valor favorece os valores deliberativos e, por conseguinte, reforça o princípio democrático. Por outro lado, o discurso de baixo valor possui conteúdo atentatório ao respeito mútuo e é caracterizado, principalmente, pelo uso de palavras incitadoras de violência. 
Entendidos como expressões de baixo valor, tais expressões não contribuem para os valores deliberativos, mas os entravam.

Pode-se dizer que a liberdade de realizar um discurso de baixo valor, com o uso de palavras incitadoras de violência ou difamação constitui uma liberdade fundamental? Merece a mesma proteção que um direito fundamental sistemática e constitucionalmente concebido?

Ora, o discurso de ódio incentiva reações imoderadas, o que debilita a cultura do respeito mútuo, necessária para as diversas manifestações e para a consideração efetiva de diferentes pontos de vista. O discurso do ódio tipicamente concebido inviabiliza um discurso mais profundo, pois seu conteúdo possui o poder de silenciar suas vítimas, fazendo com que o debate perca qualidade, os destinatários do discurso tenham sua representação reduzida e, consequentemente, interesses afetados. Os custos da prática desse tipo de discurso atingem em maior medida grupos historicamente marginalizados, o que atinge frontalmente a igualdade e põe em cheque a interpretação libertária da Primeira Emenda.

Esse efeito silenciador produzido pelo discurso de ódio também gera efeitos na esfera de liberdade individual dos sujeitos. Isso demonstra que, mesmo sob uma leitura libertária, o objetivo principal da proteção do direito à liberdade insculpido na Primeira Emenda da Constituição norte-americana não atinge sua eficácia, pois a restrição da liberdade já operou efeitos nos destinatários do discurso de ódio.

A partir dessa compreensão da experiência norte-americana, é possível traçar alguns pontos de distinção do que vem sendo construído no Brasil. A jurisprudência brasileira tem fincado estacas intelectivas no sentido de limitar o exercício da liberdade de expressão quando confrontada com outros valores de relevante estima para o Estado Democrático Constitucional de Direito.

O próprio julgamento do $\mathrm{HC} 82424$ representa o marco dessa mitigação do direito à liberdade de expressão pelo STF, o qual exarou 
posicionamento marcante, que ecoa seus efeitos na doutrina e jurisprudência até os dias atuais. 


\section{CAPÍTULO 4 - DESAFIOS ATUAIS}

\subsection{Liberdade de Imprensa: A Influência da Mídia como Óbice à Efetivação de Garantias Fundamentais}

\subsubsection{Os Excessos na Publicidade de Julgamentos Criminais}

Em tempos de "Lava-Jato"58 tudo que se veicula na mídia tem a potencialidade de gerar efeitos sancionatórios antes mesmo de proferido julgamento aos acusados. Esse fenômeno pode causar efeito inverso à promoção da garantia democrática da liberdade de informação e atingir a esfera individual de indivíduos que sequer serão condenados.

É clara a existência de uma colisão entre o direito à liberdade de expressão, comunicação, imprensa e informação, de um lado, e o direito a um julgamento criminal justo, de outro. Isso pode ser aferido sem que se aprofunde em conteúdos de Direito Penal, mas orientando-se pelo princípio da dignidade da pessoa humana, que, por sua vez, informa o rol de garantias penais constante da $\mathrm{CF} / 88$.

É indiscutível a importância da manutenção do exercício da liberdade de expressão e comunicação pela imprensa e mídias em geral, pois a sustentação do regime democrático pressupõe o acesso a informações que possibilitem o controle do aparato estatal por parte dos cidadãos. A este fato soma-se a concepção de que os julgamentos criminais dizem respeito diretamente ao interesse público.

\footnotetext{
58 “A Operação Lava Jato é a maior investigação sobre corrupção conduzida até hoje no Brasil. Ela teve início no Paraná, em 17 de março de 2014, unificando quatro ações que apuravam redes operadas por doleiros que praticavam crimes financeiros com recursos públicos. O nome Lava Jato era uma dessas frentes iniciais e fazia referência a uma rede de postos de combustíveis e lava a jato de veículos, em Brasília, usada para movimentação de dinheiro ilícito de uma das organizações investigadas inicialmente. Desde então, a operação descobriu a existência de um vasto esquema de corrupção na Petrobras, envolvendo políticos de vários partidos e algumas das maiores empresas públicas e privadas do país, principalmente empreiteiras. Os desdobramentos não ficaram restritos à estatal e às construtoras. As delações recentes da JBS e braços da operação espalhados pelo Brasil e exterior são exemplos das novas dimensões que a investigação ainda pode atingir. A duração permanece imprevisível." (FOLHA DE SÃO PAULO. Disponível em: http://arte.folha.uol.com.br/poder/operacao-lava-jato/\#capitulo1. Acesso em 27 out. 2018.)
} 
Ocorre que o acompanhamento midiático pode comprometer o próprio resultado do julgamento, alargando a desvantagem de determinado réu. Para aferir se essa assertiva aplica-se a determinado caso, deve-se proceder a avaliação do conteúdo da expressão ${ }^{59}$. A reportagem prejudicial pode ser caracterizada pela leniência do judiciário na condução do caso, culminando na divulgação parcial das informações, com versões e dados manipulados que servem aos interesses dos grupos que dominam os meios de comunicação ${ }^{60}$.

A doutrina traz a previsão do trial by media, segundo o qual a mídia é responsável por usurpar a função judicial, criando uma espécie de processo paralelo, cuja condução não observa as garantias processuais previstas no ordenamento. O resultado dessa conjuntura, normalmente, consiste na pressão do judiciário por parte da opinião pública para que a decisão se opere em determinado sentido. Logo, o trial by media caracteriza-se pela potencialidade do risco de que as reportagens prejudiciais interfiram no resultado do julgamento.

Não pairam dúvidas sobre a natureza republicana do princípio da publicidade e sua importância para a manutenção do Estado Democrático de Direito $^{61}$. Isso é fato. $\mathrm{O}$ que se questiona são os limites dessa publicidade, considerando sua influência no processamento dos julgamentos criminais.

\footnotetext{
${ }^{59}$ A esse respeito, Luís Roberto Barroso afirma: "É necessário redobrada cautela quando se trata de limitar a liberdade de expressão em razão do conteúdo das ideias manifestadas. É preciso evitar a todo custo que este direito fundamental tão importante para a vitalidade da democracia e para a autorealização individual torne-se refém das doutrinas morais majoritárias e das concepções sobre o "politicamente correto", vigentes em cada momento histórico. A liberdade de expressão não existe só para proteger as opiniões que estão de acordo com os valores nutridos pela maioria, mas também aquelas que chocam e agridem. E daí vem a grande indagação que envolve o nosso tema: até que ponto é possível restringir a liberdade de expressão para proteger direitos fundamentais de grupos estigmatizados, sem deslizar na "rampa escorregadia" (slipery slope) que pode levar à submissão do exercício deste direito às ortodoxias morais ou políticas de ocasião?" (BARROSO, Luis Roberto. Colisão entre liberdade de expressão e direitos da personalidade. Critérios de ponderação. Interpretação constitucionalmente adequada do código civil e da lei de imprensa. Revista de Direito Privado - RDPriv, ano 05, n. 18, abr./jun. 2004.)

${ }^{60}$ SCHREIBER, Simone. A publicidade opressiva de julgamentos criminais. Rio de Janeiro:

Renovar, 2008, p. 375.

61 "Ora, se a publicidade está inscrita entre as garantias constitucionais - e, afinal de contas, com todos os riscos inevitáveis, é bom que assim seja -, cumpre levá-la a sério. De nada vale franquear o espetáculo a todos os eventuais interessados e depois representar em idioma que só os happy few
} 
Seguindo a lógica de que os fins justificam os meios, o Brasil tem experimentado uma dose de insegurança jurídica em relação a determinadas garantias constitucionais. Primeiramente, cabe citar a decisão proferida pelo Supremo Tribunal Federal, por maioria de votos, no julgamento do $\mathrm{HC}^{\circ}$ 126.292/SP. Nele foi decidido pela possibilidade da execução provisória da pena após condenação em segundo grau de jurisdição, ou seja, antes de encerrado o processo.

Essa decisão representa interpretação discutível do princípio da presunção de inocência ${ }^{62}$, que condiciona a prisão ao trânsito em julgado da sentença penal condenatória. Diante dos fatos, pode-se dizer que a possibilidade de execução provisória da pena após o esgotamento do duplo grau de jurisdição foi desencadeada pela influência social e forte campanha midiática em prol do "fim da impunidade" 63 .

Há um grande perigo quando se coloca em xeque direitos e garantias fundamentais para dar voz ao clamor social que ecoa em determinado sentido. Isto porquê os meios de comunicação de massa são verdadeiros instrumentos de manipulação do consenso na sociedade, pois não se restringem a veicular a notícia original, mas compõem a própria versão dos

\footnotetext{
compreendem. Não nos iludamos: uma parte, cada vez maior, da sociedade brasileira está aprendendo a cobrar explicações e não se resignará indefinidamente a que os poderes públicos a mantenham na ignorância dos processos decisórios, sejam quais forem. De instante a instante aumentará o número dos que querem saber como se decide, e porquê. O Judiciário não vai escapar a essa mirada perscrutadora; convém que esteja preparado para explicar-se: é o preço que tem de pagar para assegurar a si próprio o mínimo de credibilidade sem o qual não poderá exercer de maneira satisfatória, do ponto de vista social, a função de árbitro supremo dos conflitos de interesses." (BARBOSA MOREIRA, José Carlos. A justiça no limiar do novo século. O processo civil brasileiro: Uma apresentação. Temas de direito processual: quinta série. São Paulo: Saraiva, 1994. p. 25-37, esp. p. 34-35)

62 Constituição da República Federativa do Brasil.

BRASIL Constituição (1988) Art. 5, LVII.

Disponível em: http://www.planalto.gov.br/ccivil_03/constituicao/constituicaocompilado.htm.

Acesso em 30 out. 2018.

${ }^{63} \mathrm{O}$ princípio da presunção de inocência, como medida de civilidade de um sistema jurídicoconstitucional, não pode ser sacrificado no altar do trial by media, imposto pelos meios de comunicação de massa, com a condenação apriorística do investigado ou do imputado. A não ser assim, restará desafiado o princípio da estrita jurisdicionalidade, com patente vilipêndio, também, dos princípios fundamentais do juiz natural, da ampla defesa, do contraditório e do devido processo legal. (CONTE, Francesco. A influência social na determinação da lei penal: uma perspectiva da espetacularização midiática. Texto não publicado, mas gentilmente cedido pelo autor).
} 
fatos. Tão notório quanto se queira perceber, a comunicação midiática mostra-se parcial e infiel à realidade do que é narrado ${ }^{64}$.

Assim, a manipulação de informações, sob a forma de verdade oficial, por alguns setores da mídia, produz, paradoxalmente, desinformação. A velocidade do fluxo de informações mantém as pessoas na superfície das notícias. De forma que se torna impossível separar o que é relevante do que não é. A relativização do que é atual faz com que no minuto seguinte deixe de sê-lo. É um método midiático que tem por finalidade ludibriar a opinião pública.

\subsection{O protagonismo do Poder Judiciário no Campo da Realização dos Direitos Fundamentais: Influxo da Mídia e Seus Efeitos}

Em uma sociedade complexa, os fenômenos como a rede mundial de computadores, os transportes intercontinentais e o comércio internacional se entrelaçam em um boom de globalização que tende a se expandir em intervalo de tempo cada vez mais exíguo. Com a potencialização das relações, surgem conflitos de diversas naturezas. O desafio maior passa a ser a administração das diferenças no seio de uma sociedade extremamente plural. Essa tarefa é exercida em grande medida pelo Judiciário.

O compromisso do Judiciário com a efetivação dos direitos fundamentais tem seu sustentáculo na ideia de Separação dos Poderes, cujo reconhecimento data de momento histórico pretérito ao atual. Todavia, é

\footnotetext{
${ }^{64}$ Há ainda o risco de que os juízes sejam permeáveis pelo clamor público (provocado e ao mesmo tempo repercutido pela imprensa) no sentido de que crimes que tenham recebido maior atenção da mídia sejam punidos rápida e exemplarmente, ainda que a condenação esteja pautada na versão dos fatos inicialmente divulgadas (aquelas apuradas pela polícia ou pelos próprios jornalistas), e que sejam desprezadas as garantias do devido processo legal. Constata-se assim a possibilidade de que as demandas fomentadas pela mídia e dirigidas ao Judiciário não sejam "justas", entendida a solução justa do processo como aquela a qual se chegou após o devido processo legal, respeitadas portanto as garantias constitucionais que abarcam o conceito de julgamento justo. E que a "verdade" sustentada pela imprensa, com base na qual o veredicto condenatório é propugnado, não coincida necessariamente com a verdade processual (novamente a verdade construída sob o devido processo legal). (SCHREIBER, 2008, p. 372-373.)
} 
importante relembrar o motivo pelo qual fala-se em Separação de Poderes, sobretudo quando do estremecimento da credibilidade das instituições.

No constitucionalismo contemporâneo, a Separação de Poderes passou a ser dotada de contornos que vão além da contenção do poder, mas promovem a legitimação democrática do governo, assim como a eficiência da ação estatal ao empreender a efetiva realização de direitos fundamentais. O que reflete diretamente a busca por arranjos estruturais no enfrentamento dos desafios do Estado ${ }^{65}$.

A responsabilidade do juiz na realização do propósito para o qual foi direcionado pelo texto constitucional agrega a compreensão de que a margem de discricionariedade a que está submetido possui limites que devem ser observados na prática diária ${ }^{66}$.

O julgamento do ex-presidente Luiz Inácio Lula da Silva, cuja cobertura da mídia foi ampla e contou com o efeito multiplicador da internet, representa um exemplo da influência da mídia sobre o imaginário popular e em outra direção, a pressão popular sobre os elementos de convencimento do juiz no caso $^{67}$.

\footnotetext{
${ }^{65}$ SARMENTO, 2015, p. 306.

${ }^{66}$ A defesa de Luís Roberto Barroso é de que apesar do papel criativo do juiz, este deve atender certos limites: $\mathrm{O}$ fato inafastável é que a interpretação jurídica nos dias atuais, reserva para o juiz um papel muito mais proativo, que inclui atribuição de sentido a princípios abstratos e conceitos jurídicos indeterminados, bem como a realização de ponderações. Para além de uma função puramente técnica de conhecimento, o intérprete judicial integra o ordenamento jurídico com suas próprias valorações, sempre acompanhadas do dever de justificação. Discricionariedade judicial, portanto, traduz o reconhecimento de que o juiz não é apenas a boca da lei, um mero exegeta que realiza operações formais. Existe uma dimensão subjetiva na sua atuação. Não a subjetividade da vontade política própria - que fique bem claro -, mas a que inequivocamente decorre da compreensão dos institutos jurídicos, da captação do sentimento social e do espírito de sua época. (BARROSO, Luis Roberto. A razão sem voto: o Supremo Tribunal Federal e o governo da maioria. Revista de Direito da Procuradoria Geral do Estado do Rio de Janeiro. Junho 2017.)

67 “o julgamento de Lula é uma catástrofe sem precedentes na história política brasileira. Isto porque fica validada a versão de 'faxineiro moral' que têm reivindicado para si boa parte do sistema de justiça brasileiro, de forma mais organizada desde o julgamento do mensalão. Consagra-se o estado policial vitorioso na sua luta contra o estado garantista. Que fique claro que não se trata de uma disputa doutrinária ou ideológica entre acadêmicos criminalistas. Se trata aqui de, ancorada na ideologia de combate à corrupção, legitimação de novas práticas jurídico-políticas, nocivas ao casamento da democracia com o estado de direito. Práticas como o uso polêmico da teoria do domínio do fato, a combinação da prisão preventiva com a delação premiada, os vazamentos seletivos de material probante, a espetacularização das operações de cumprimento de mandados, as coletivas e notas à imprensa, os descompensados posts em redes sociais." (JOTA. O julgamento de Lula: o ocaso do Direito brasileiro. Disponível em: https://www.jota.info/opiniao-e-
} 
Vejamos.

Havia clara insatisfação em relação à manutenção do Partido dos Trabalhadores no poder, o que se concretizou com o impeachment da expresidenta Dilma Roussef.

Diante desse contexto, a promessa redentora de membros do judiciário, diante do confronto no seio da Operação Lava Jato, passou a ser a mensagem central a ecoar na mente da sociedade, que diariamente consumia conteúdo de informação endossando o discurso do herói e do bandido ${ }^{68}$.

A imagem do partido estava desgastada, muito em função do processo judicial que levou à prisão membros importantes da legenda. O papel da mídia, nesse contexto, foi além do compromisso com a informação, mas exerceu certa influência na formação do consenso anti-PT, movimento que alcançou maior visibilidade durante o processo eleitoral de 2018.

O perigo nesses casos é de que o processo deixe de reger-se pelas provas constantes dos autos, passando a ser instruído por concepções genéricas de justiça, hasteando-se sempre a bandeira do combate a corrupção, tal qual um dogma ${ }^{69}$.

analise/colunas/judiciario-e-sociedade/o-julgamento-de-lula-o-ocaso-do-direito-brasileiro02022018. Acesso em 01 nov. 2018.

${ }^{68}$ Quando a racionalidade é substituída pela ilusão cinematográfica, os meios de comunicação em massa podem incensar juízes estimulando-lhes ideias delirantes sobre seu próprio papel na comunidade em que opera. Criam uma classe de "juízes estrelas", com inegáveis riscos de ruptura de seu dever de imparcialidade. O juiz inebriado pelos holofotes da mídia tende a produzir rumor revestido de legalidade. (CONTE, Francesco. A influência social na determinação da lei penal: uma perspectiva da espetacularização midiática. Texto não publicado, mas gentilmente cedido pelo autor).

69 "Uma grande empreiteira, com contratos vultuosos com o governo brasileiro, reservou um apartamento luxuoso em um de seus empreendimentos imobiliários para um ex-presidente, em cujo governo essa mesma empreiteira se esbaldou em contratos bilionários que dependiam de suas indicações políticas. Se para você isso é motivo suficiente para mandar esse ex-presidente para a cadeia, não há o que criticar no julgamento de Lula pela justiça federal. No entanto, se, por outro lado, você acredita que deve haver prova específica da ligação entre a vantagem recebida pelo político corrupto e seu ato em benefício do agente corruptor e considera suspeita essa prova se ela se baseia exclusivamente em depoimentos de delatores que visam escapar da prisão, nesse caso, você pode se revoltar contra o julgamento, pois tal prova, para além dos depoimentos, não existe." (JOTA. Julgamento de Lula envolve divergências genuinamente jurídicas. Disponível em: https://www.jota.info/stf/supra/julgamento-de-lula-envolve-divergencias-genuinamente-juridicas26012018. Acesso em 01 nov. 2018) 
Se por um lado a judicialização da política apresenta ameaças à ordem democrática, a politização do Judiciário pode representar a ruptura com a imparcialidade do juiz, as motivações cada vez mais deficientes, assim como a quebra de compromissos com garantias mínimas de um devido processo legal. A grande preocupação do judiciário, diante de tais desafios - que são inerentes à democracia e ao exercício das liberdades - deve ser a busca pela imparcialidade e a consciência sobre a essencialidade de seu papel na manutenção do Estado Democrático de Direito ${ }^{70}$.

Portanto, diante da crise que assola a credibilidade das instituições, é importantíssimo que se promova o fortalecimento das garantias constitucionais como forma de combate às arbitrariedades de qualquer autoridade que se levante contra a ordem constitucional vigente, a mesma que foi conquistada a duras penas, sob uma História escrita, sobretudo, com muita coragem.

\footnotetext{
${ }^{70}$ Neste ponto, muito esclarecedores também os artigos dos Professores Maria Luiza Quaresma Tonelli - Judicialização da Política - e Afrânio Silva Jardim - Lava Jato - In: ENCICLOPÉDIA DO GOLPE, organizado por Barbara Caramuru Teles. Bauru, 2017. P. 87/96 e 106/118, respectivamente.
} 


\section{CONCLUSÃO}

O objetivo deste trabalho foi analisar o desenvolvimento do direito à liberdade de expressão, os modos como seu exercício impacta a vida em sociedade e as possibilidades de mitigação desse direito em face de outros direitos de mesma monta na estrutura constitucional brasileira.

O trabalho foi estruturado traçando-se um breve panorama histórico sobre a evolução do constitucionalismo, abordando-se a trajetória de países precursores e sua influência na estruturação do constitucionalismo no Brasil. Nesse sentido, destacou-se a importância da interpretação constitucional e os mecanismos de controle previstos na $\mathrm{CRFB} / 88$, que ganharam força com $\mathrm{o}$ surgimento do Estado Democrático de Direito.

Nesse cenário, a Constituição passa a representar o principal documento de direitos, localizada no topo do ordenamento jurídico e tem sua força normativa reconhecida, podendo fazer-se aplicar direta e imediatamente. Tal reconhecimento foi essencial para a efetiva realização dos direitos fundamentais, que, além de conteúdo imperioso no modelo de Estado que se pretende elevar, são ferramentas indispensáveis na tarefa de interpretação e aplicação do direito.

Os direitos fundamentais, cuja oponibilidade em face do Estado é inquestionável desde de sua instituição, tiveram sua oponibilidade perante terceiros reconhecida pelo STF, demonstrando certa preocupação do judiciário no cumprimento de suas disposições como forma de realizar o Estado democrático.

A grande tarefa do segundo capítulo é a contextualização da liberdade de expressão no Brasil. Para tanto, inicialmente, faz-se uma demonstração de alguns dos momentos históricos em que o Brasil foi palco de governos autoritários. Em seguida, como a liberdade de expressão foi tratada na CFRB/88, coroando a redemocratização, pós ditadura militar. 
Nesse enquadramento, passa-se a admitir a possibilidade de mitigação do direito à liberdade de expressão, o qual, diante de conflitos com outros direitos fundamentais, terá sua aplicação avaliada de acordo com o caso concreto. Para isso, adota-se a ponderação como procedimento hermenêutico de aplicação da norma. De modo que a norma aplicável será aquela que se sobreponha diante da situação fática.

O terceiro capítulo trata da ponderação como procedimento lógico de identificação da norma prevalente diante do caso concreto. Em face da colisão normativa, a ponderação é o método pelo qual o aplicador da norma definirá, com base em parâmetros gerais e específicos previamente estabelecidos - ou pensados especificamente para a solução dos chamados hard cases - qual a norma prevalecerá diante das peculiaridades da demanda.

Além disso, esse capítulo presta-se à apresentação do discurso de ódio e à possibilidade de limitação da liberdade de expressão com o intuito de fazer prevalecer o princípio da dignidade humana.

O quarto capítulo volta-se à análise da influência da mídia na atuação do Poder Judiciário. Nesse capítulo, o esforço foi no sentido de demonstrar que a imparcialidade do juiz é um dos elementos mais importantes no enfrentamento da mídia nociva. Foi por essa razão que o trabalho prestou-se à análise de alguns pontos do julgamento do ex-presidente Lula com o objetivo de identificar possíveis falhas.

Por fim, cumpre ratificar a importância da liberdade de expressão, seja para a manifestação individual de ideias ou para a difusão de informações. $O$ que não the confere a natureza de direito absoluto, dado que quando em rota de colisão com outros direitos, pode dar lugar a prevalência de outro direito no caso concreto.

No ano em que completa seus 30 anos, a Constituição da República Federativa do Brasil, principal documento de direitos do país, símbolo maior da democracia, testemunhou grandes manifestações de apreço, desapreço e até indiferença em relação ao princípio democrático. 
As eleições de 2018 mostraram que nenhuma conquista está imune aos efeitos manipuladores da mídia em geral, o que rememora a ironia da democracia. Avante. A luta não para. 


\section{REFERÊNCIAS BIBLIOGRÁFICAS}

ALEXY, Robert. Teoría de los Derechos Fundamentales. - de la traduccion y estudio introductorio, Carlos Bernal Pulido. - Centro de Estudios Políticos y Constitucionales. - Madrid, 2014.

ALMEIDA, Luiz Antônio Freitas de. Direitos fundamentais sociais $e$ ponderação: ativismo irrefletido e controle jurídico racional. Porto Alegre: Sergio Antonio Fabris Ed., 2014. 352p.

BARBOSA MOREIRA, José Carlos. A justiça no limiar do novo século. $O$ processo civil brasileiro: Uma apresentação. Temas de direito processual: quinta série. São Paulo: Saraiva, 1994. p. 25-37, esp. p. 34-35

BARCELlOS, Ana Paula de. Alguns parâmetros normativos para a ponderação constitucional apud A nova interpretação constitucional: ponderação, direitos fundamentais e relações privadas / Luís Roberto Barroso (organizador) $-3^{\text {a }}$ ed. Revista - Rio de Janeiro: Renovar, 2008. p. 49-118

BARROSO, Luis Roberto. A razão sem voto: o Supremo Tribunal Federal e o governo da maioria. Revista de Direito da Procuradoria Geral do Estado do Rio de Janeiro. Junho 2017.

. Colisão entre liberdade de expressão e direitos da personalidade. Critérios de ponderação. Interpretação constitucionalmente adequada do código civil e da lei de imprensa. Revista de Direito Privado - RDPriv, ano 05, n. 18, abr./jun. 2004. 
- Interpretação e aplicação da constituição: fundamentos de uma dogmática constitucional transformadora. 3ed., Saraiva. São Paulo, 1999.

BRASIL. Lei $\mathrm{n}^{\circ}$ 5.250, de 09 de fevereiro de 1967. Regula a liberdade de manifestação do pensamento e de informação. Disponível em: http://www.planalto.gov.br/ccivil_03/LEIS/L5250.htm. Acesso em 13 jul. 2018.

COMPARATO, Fábio Konder. A afirmação histórica dos direitos humanos. $10^{\mathrm{a}}$ ed. São Paulo: Saraiva, 2015. 619 p.

Constituição da República Federativa do Brasil.

BRASIL. Constituição (1988).

Disponível em:

http://www.planalto.gov.br/ccivil_03/constituicao/constituicaocompilado.htm Acesso em 22 ago. 2018.

CONTE, Francesco. Sobre a motivação da sentença no processo civil: Estado constitucional democrático de direito, discurso justificativo e legitimação do exercício da jurisdição. $1^{\mathrm{a}}$ ed. Rio de Janeiro: Gramma, 2016. 1044 p.

. A influência social na determinação da lei penal: uma perspectiva da espetacularização midiática. Texto não publicado, mas gentilmente cedido pelo autor.

Convenção Americana de Direitos Humanos. Costa Rica, 1969. Disponível em: https://www.cidh.oas.org/basicos/portugues/c.convencao_americana.htm. Acesso em 10 ago. 2018. 
DWORKIN, Ronald. Levando os direitos a sério; tradução Nelson Boeira. $3^{\mathrm{a}} \mathrm{ed}$. São Paulo: Editora WMF Martins Fontes, 2010. 564 p.

FARIAS, Edilsom. Liberdade de Expressão e Comunicação. Teoria e proteção constitucional. São Paulo: Editora Revista dos Tribunais, 2004.

FISS, Owen M. A ironia da liberdade de expressão: estado, regulação e diversidade na esfera pública; tradução e prefácio de Gustavo Binenbojm e Caio Mário da Silva Pereira Neto. - Rio de Janeiro: Renovar, 2005. 144p.

FOLHA DE SÃO PAULO. Disponível em: http://arte.folha.uol.com.br/poder/operacao-lava-jato/\#capitulo1. Acesso em 27 out. 2018.

HESSE, Konrad. A força normativa da constituição. Tradução de Gilmar Ferreira Mendes. Sergio Antonio Fabris Editor: Porto Alegre, 1991.

LEITE, Fábio Carvalho. Liberdade de Expressão e Direito à Honra: Novas Diretrizes para um Velho Problema. In: CLÈVE, Clèmerson Merlin; FREIRE, Alexandre (Org.). Direitos fundamentais e Jurisdição Constitucional: Análise, Crítica e Contribuições. $1^{a}$ ed. São Paulo: Revista dos Tribunais, 2014. p. 395408

JOTA. O julgamento de Lula: o ocaso do Direito brasileiro. Disponível em: https://www.jota.info/opiniao-e-analise/colunas/judiciario-e-sociedade/ojulgamento-de-lula-o-ocaso-do-direito-brasileiro-02022018. Acesso em 01 nov. 2018. 
. Julgamento de Lula envolve divergências genuinamente jurídicas. Disponível em: https://www.jota.info/stf/supra/julgamento-de-lula-envolvedivergencias-genuinamente-juridicas-26012018. Acesso em 01 nov. 2018

JOTA. Julgamento de Lula envolve divergências genuinamente jurídicas. Disponível em: https://www.jota.info/stf/supra/julgamento-de-lula-envolvedivergencias-genuinamente-juridicas-26012018. Acesso em 01 nov. 2018

LEITE, Fábio Carvalho. Liberdade de Expressão e Direito à Honra: Novas Diretrizes para um Velho Problema apud CLÈVE, Clèmerson Merlin; FREIRE, Alexandre. Direitos fundamentais e Jurisdição Constitucional: Análise, Crítica e Contribuições. $1^{\text {a }}$ ed. São Paulo: Revista dos Tribunais, 2014. p. 395-408.

MARSHALL, John, and Supreme Court Of The United States. U.S. Reports: Marbury v. Madison, 5 U.S. 1 Cranch 137. 1803. Periodical. Retrieved from the Library of Congress. Disponível em: http://cdn.loc.gov/service/11/usrep/usrep005/usrep005137/usrep005137.pdf. Acesso em 29 set. 2018

MORAES, Alexandre de. Direito constitucional. 29ª ed. São Paulo: Atlas, 2013.

NETO, Cláudio Pereira de Souza; SARMENTO, Daniel. Direito Constitucional: teoria, história e métodos de trabalho. Belo Horizonte: Fórum, 2014. $624 \mathrm{p}$.

RIBEIRO, Darcy. Povo brasileiro: a formação e o sentido do Brasil. São Paulo: Companhia das Letras, 1995. 313 p. 
RODRIGUES, José Honório. A assembleia constituinte de 1823. Petrópolis: Editora Vozes, 1974, 325 p.

SARMENTO, Daniel. A liberdade de expressão e o problema do "hate speech". Disponível em: http://www.dsarmento.adv.br/content/3-publicacoes/19-aliberdade-de-expressao-e-o-problema-do-hate-speech/a-liberdade-deexpressao-e-o-problema-do-hate-speech-daniel-sarmento.pdf. 58 p. Acesso em 24 set. 2018.

SCHREIBER, Simone. A publicidade opressiva de julgamentos criminais. Rio de Janeiro: Renovar, 2008, p. 375.

SILVA, José Afonso da. Aplicabilidade das normas constitucionais. $3^{\text {a }}$ ed., Brasil: Malheiros Editora, 1998.

. Curso de direito constitucional positivo. $41^{\mathrm{a}}$ ed., rev. e atual./até a Emenda Constitucional n. 99, de 14.12.2017. São Paulo: Malheiros, 2018.

STF, ADI 4.815/DF. Rel. Min. Carmen Lúcia, Brasília, 16 fev. 2016.

STF, HC 82424-2/RS. Rel. Ministro Moreira Alves. Brasília, 19 mar. 2004.

STF. RE 201819/RJ, Rel. Min. Ellen Gracie, Rel. p/ acórdão Min. Gilmar Mendes, Brasília, 27 out. 2006.

TONELLI, Maria Luiza Quaresma. Judicialização da Política; JARDIM, Afranio Silva. Lava Jato. In: Giovanni Alves et al. (coordenador). Enciclopédia do Golpe. Bauru: Canal 6, 2017. P.87-96 e 106-118. 